\title{
Site-specific Equivalent Linear Response Analysis and Liquefaction Hazard Evaluation of Hawassa Town, Main Ethiopian Rift
}

\author{
Alemayehu Ayele ( $\sim$ alex98geo@gmail.com ) \\ Addis Ababa Science and Technology University https://orcid.org/0000-0001-8571-8721 \\ Kifle Woldearegay \\ Mekelle University \\ Matebie Meten \\ Addis Ababa Science and Technology University
}

\section{Research}

Keywords: Shear wave velocity, Factor of safety, equivalent linear response analysis, Liquefaction hazard evaluation

Posted Date: October 26th, 2021

DOI: https://doi.org/10.21203/rs.3.rs-983279/v1

License: (c) (i) This work is licensed under a Creative Commons Attribution 4.0 International License. Read Full License 
Site-specific equivalent linear response analysis and liquefaction hazard evaluation of Hawassa town, Main Ethiopian Rift

\author{
Alemayehu Ayele ${ }^{12}$ and Kifle Woldearegay ${ }^{3}$ and Matebie Meten ${ }^{1}$ \\ ${ }^{1}$ Department of Geology, College of Applied Science, P.O.Box.16417 Addis Ababa Science and \\ Technology University, Ethiopia \\ ${ }^{2}$ Department of Geology, College of Natural and Computational Science, Wachamo University, \\ P.O.Box. 667, Hosanna, Ethiopia (alex98geo@ gmail.com)
}

${ }^{3}$ School of Earth Sciences, P.O.Box. 231, Mekelle University, Mekelle, Ethiopia (kiflewold@gmail.com)

\begin{abstract}
Liquefaction is one of the geotechnical earthquake issues when a soil subjected to high strain due to dynamic loading and causes damage of the infrastructure. The main objective of this study is to predict the ground motion parameter and evaluate the potential of soil to liquefaction in Hawassa town. The site was characterized and classified based on the SPT-N values and average shear wave velocity (Vs30). The SPT-N value in Hawassa town ranges from 5-50. Whilst the Vs30 varies from $245-365 \mathrm{~m} / \mathrm{s}$. The site class was C and D based on the NEHRP (2015) whereas $\mathrm{B}$ and $\mathrm{C}$ based on the EC8 (2003). The effects of the liquefaction are predicted using equivalent linear response analysis and liquefaction hazard evaluation methods at the five typical sites. Equivalent linear response analysis was used to determine local site effect in terms of PGA (g), SA (g) and maximum strain (\%).Whereas the liquefaction hazard evaluations were done by liquefaction susceptibility criteria, factor of safety (FS), liquefaction potential index (LPI), probability of liquefaction (PL) and probability of liquefaction induced ground failure (PG). The predicted ground motion parameter shown: (i) PGA (g) values at surface ranges from $0.16 \mathrm{~g}$ to $0.27 \mathrm{~g}$, (ii) the maximum strain (\%) is less than 0.01 and (iii) the SA (g) vary from $0.7 \mathrm{~g}$ to $1.2 \mathrm{~g}$ with in the period interval of $0.1 \mathrm{se}$ and $1 \mathrm{sec}$. The FS was less than unity for the typical one site and greater than unity for the other typical 4 sites. As a result, the liquefaction will be occurred only at the typical one site than other typical four sites for the given input motion. It is also evident that the typical one site has very high LPI, very likely to the PL and extremely high to PG than the other typical four sites. The findings from the present study will be helpful in retrofitting, analysis, design of structures and solving practical challenges in earthquake engineering.
\end{abstract}


Key words: Shear wave velocity; Factor of safety; equivalent linear response analysis; Liquefaction hazard evaluation

\section{Introduction}

Liquefaction hazard evaluation is an integral part of seismic hazard analysis for earthquake prone areas. Liquefaction is a phenomenon at which the strength and stiffness of a soil is reduced by earthquake shaking and increased pore water pressure (Papathanassiou et al. 2011; Tehran et al. 2016; Bahari et al. 2020). Also, liquefaction is the transformation of granular soils from a solid state to a liquefied state due to excess pore water pressure and reduced effective stress during an earthquake (Marcuson 1978).

The soil liquefaction is one of the seismic hazards in a saturated loose sand, silt and silty sand soil during earthquake ground motion (Rahman and Siddiqua 2017). As a result, soil liquefaction is causes primary damages like lateral spreading, fissures (ground cracking), differential movements and sand boils in saturated loose soil deposits during earthquakes (Kramer 1996; Bird and Bommer 2004; Sana and Nath 2016). The secondary damages due to liquefaction effects result in the destruction of transportation infrastructure, energy transmission lines, municipal water infrastructure, wastewater facilities, communication lines, bridges, roads, dam structures and loss of human life (Yoshida et al. 2001; Seged and Haile 2010). Therefore, the evaluation of liquefaction potential is an important component of geotechnical site characterization for seismic hazard assessment in earthquake prone areas.

The laboratory and field test is used to determine the liquefaction resistance of soils (Rahman and Siddiqua 2017). The high quality undisturbed soil samples are required to perform laboratory tests for the evaluation of liquefaction hazard analysis. However, the laboratory test is seldom and costly to collect undisturbed samples from saturated loose gravel, sand, silt and silty sand soils. So, in situ tests are commonly used for the evaluation of seismic liquefaction resistance of soils. Shear wave velocity (Vs) based liquefaction and local site effects are the best method used to address liquefaction resistance of soil and prediction of ground motion parameters (Seed and Idriss 1971; Seed and Peacock 1971; Seed et al. 1984; Rahman et al. 2018; Akkaya et al. 2018; Akkaya and Özvan 2019: Ayele et al. 2021). The equivalent linear response analysis is used to 
evaluate site specific geological effects (Kramer 1996; Hashash et al. 2020). To assess the liquefaction effect, it is imperative to determine the liquefaction susceptibility of soil using screening criteria in the tectonically active region (Tsuchida 1970; Sana and Nath 2016). The parameters have proposed to decipher the effect and susceptibility of liquefied soils are grain size, geological age and origin, relative density, earthquake loading characteristics, seismic strain history, fines content and plasticity index and degree of saturation (Kramer 1996; Kavazanjian et al. 1997; Özaydın 2007).

The potential of liquefaction of the study site in earthquake prone area is evaluated using factory of safety (FS), cyclic stress ratio (CSR) and cyclic resistance ratio (CSR) (Seed and Idriss 1971). In addition to that, the deterministic approach, which is the simplified procedure based on SPT (Seed and Idriss 1971) and Vs (Uyanık et al. 2013; Tang et al. 2015) has become the standard practice for evaluating the liquefaction potential of granular soils (Youd et al. 2001; Rahman et al. 2018; Akkaya et al. 2018; Akkaya and Özvan 2019). However, the Vs-based liquefaction hazard evaluation was used for this study. The factor of safety doesn't give any idea about the liquefaction potential of a soil layer. Thus, it is not helpful for the preparation of liquefaction potential and susceptibility. As a result, considering various severity classes is used to overcome liquefaction potential and susceptibility (Juang et al. 2012). Therefore, the liquefaction potential index (LPI) proposed by Iwasaki et al (1982) later modified by Sonmez (2003) and probability of liquefaction (PL) categories based on FS proposed by Chen and Juang (2000) used to address liquefaction potential of soil layer.

\section{Materials and Methodology}

\subsection{Study area}

\subsubsection{Location}

Hawassa town, which is the study area, is located at Main Ethiopian Rift System. The Main Ethiopian Rift System is a part of East African Rift System (EAR). In addition, Hawassa town is situated along the eastern part of Lake Hawassa (Fig. 1). 


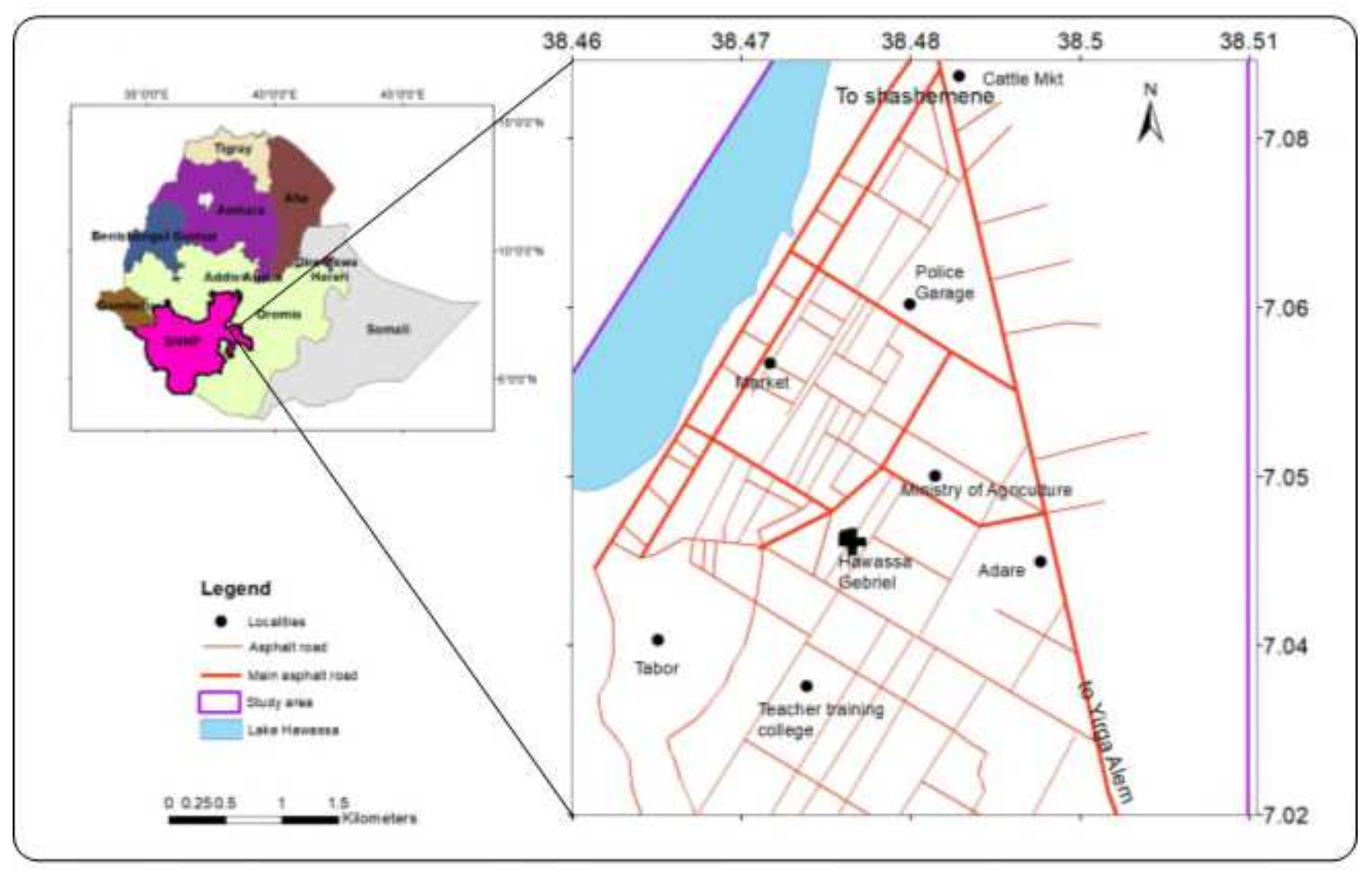

Fig. 1 Location map of the study area, Hawassa town, Southern Ethiopia

\subsubsection{Seismotectonics}

The Main Ethiopian Rift forms an active plate boundary between the Africa (Nubia) and Somalia plates in the northern East African Rift System (EARS). In addition, the Main Ethiopian Rift (MER) is the example of mature continental rifting at northernmost part of the EARS. Thus, the EARS is one of the most geologically active features on Earth (Chorowicz 2005). The MER is divided into three main sectors (Northern, Central and Southern) (Agoistini et al. 2011; Wilks et al. 2017) based on the lithospheric characteristics (Keranen et al. 2004), crustal thickness and modification (Keranen and Klemperer 2008). The study area, Hawassa town is located at the Southern Main Ethiopia (SME), which is largely fault controlled and actively deformed (Corti et al. 2013). So, Hawassa town is facing low to intermediate magnitudes earthquake (>5) in the recent years and causes damage of building and creating public worry in the town of Hawassa (Wilks et al. 2017).

Aden and 


\subsubsection{Geology}

The Hawassa geology is composed of upper Miocene to Pliocene volcanic rocks of the Nazret group dominated by rhyolitic ignimbrites that form basement of the MER (Woldegabriel 1990; Žáček et al. 2014). According to the Žáček et al. (2014), the lithological units in the study area and its surroundings are (Fig. 2).

- Fluvial sediments: These are occurred on the Tikur Woha river channel. Its sediments are composed of silt and muddy unconsolidated deposits.

- Alluvial sediments: They are formed from the weathered volcanic rock. It is also formed from fine to medium grained sands.

- Polygenetic sediments: It fills the bottom of Hawassa and Corbetti caldera. They are formed from fine to medium grained soil with a high portion of weathered volcanic rocks and angular clasts of pumice. This sediment contains silt, sand and sandy silt soil.

- Wondo Koshe pumice fall and flow deposits: This is well sorted and clast supported deposits. They were produced during the last big explosive event of the Wendo Koshe volcano.

- Scoria cone: It is poorly sorted and dominated by fragments of scoria predominantly 5$10 \mathrm{~cm}$ in diameter.

- Tuff cones: They are poorly-sorted and dominated by massive non-vesicular basaltic clasts with a prevailing grain-size of $1 \mathrm{~cm}$.

- Hawassa basalt: This was emitted from several scoria and tuff cones arranged along the ridge.

- Hawassa rhyolitic ignimbrites: They were produced by voluminous eruptions of a rhyolitic magma from the Hawasa Caldera. These ignimbrites are the oldest rocks exposed in the area of Hawassa.

A total of 19 Multichannel analysis of surface wave (MASW), 11 Standard penetration blow counts (SPT-N) (ARCON Design Build plc, 2018) and 10 borehole data (SDCSE, 2019) points are located on the geological map (Fig.2). The measurements of MASW, SPT-N and borehole were made at the lacustrine deposits. Based on the SPT-N values, borehole data and Vs, the Hawassa town contains sandy soil with small content of gravel. The local site effect for seismic hazard evaluation of Hawassa town is done on sandy soil. For this study, 5 typical sites of 
MASW, 11 SPT-N and 10 borehole data points were used for the liquefaction and site response analysis (Fig.2).

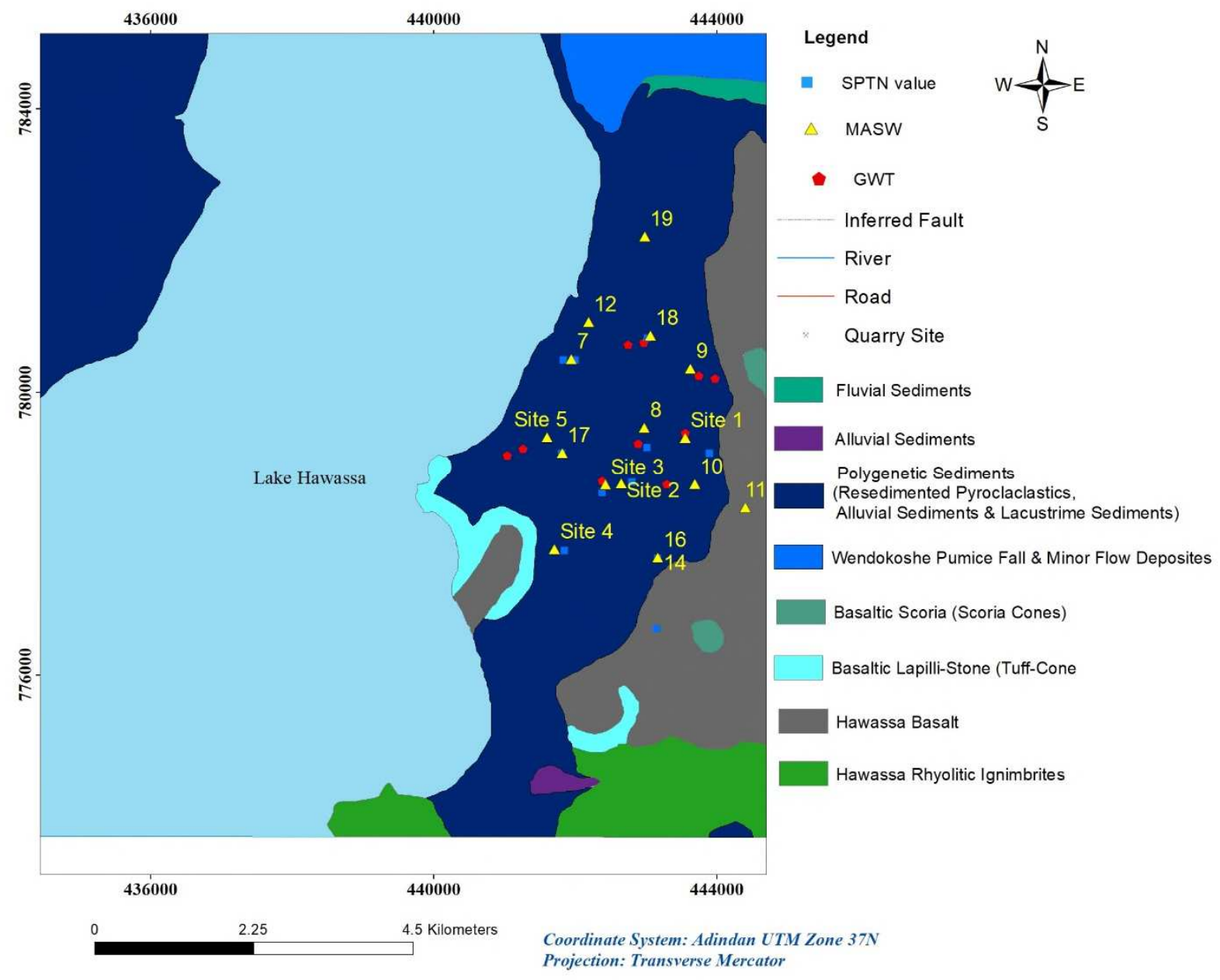

Fig.2 Geological map of study area and its surroundings (modified after Žáček et al. 2014), MASW, SPT-N and GWT data points location map of Hawassa town

\subsection{Methodology}

For this study, the following approaches were used to evaluate the liquefaction hazard analysis: (i) site characterization and classification, (ii) equivalent linear response analysis (ELA), (iii) liquefaction susceptibility, (iv) cyclic stress ratio (CSR), cyclic resistance ratio (CRR) and factor of safety (FS), (v) liquefaction potential index (LPI), (vi) probability of Liquefaction (PL) and (vii) probability of liquefaction induced ground failure (PG). The detail of all the listed methodology is given as follows. 


\section{2.1 Site characterization and classification}

Shear wave velocity (Vs) and SPT-N values are used to characterize a site. In addition, the Vs and SPT-N values are also used to classify the sites according to the seismic codes. The average shear-wave velocity to a depth of $30 \mathrm{~m}$ (Vs30) and SPT-N values is a commonly used parameter in seismic guide lines such as the National Earthquake Hazards Reduction Program (NEHRP) (2015) and EC8 (2003). The Vs and SPT-N values offers engineers a promising tool to evaluate liquefaction resistance of soils. The detailed site characterization and classifications approaches used in this study are given as follows.

MASW: This is a surface wave analysis methods and it is used to measure the shear wave velocity at the surveyed site. The shear wave velocity profile is used to determine average shear wave velocity up to a depth of $30 \mathrm{~m}(\mathrm{Vs} 30)$. The Vs30 is defined as the travel-time average shear wave velocity in the topmost $30 \mathrm{~m}$ of the subsurface. In addition, it is used to evaluate site classification, site response analysis and liquefaction analysis for seismic hazard analysis. For this study, Vs30 is calculated using the equation 1 (Boore 2004; Nath and Jakka 2012):

$$
V s 30=\frac{30 m}{\sum_{i}^{N} \frac{h i}{V i}}
$$

where Vs30 is shear wave velocity up to depth of 30 meters, Vi is shear wave velocity for the $i^{\text {th }}$ layer in $\mathrm{m} / \mathrm{s}$, hi is thickness of the $\mathrm{i}^{\text {th }}$ soil layer in meters, $\mathrm{N}$ is number of layers in the top $30 \mathrm{~m}$ soil strata which will be considered in evaluating Vs30 values.

For this study, a total of 19 MASW data points were collected for the site characterization and classification as shown Fig.2. A 5 typical sites of MASW data points were chosen for the detailed equivalent linear response and liquefaction hazard analysis based on the SPT-N, MASW and borehole data.

SPT: It is a widely used in-situ test for site characterization and classification. SPT-N values are used to evaluate dynamic properties of soil. A total of 11 SPT-N values were used to evaluate the stiffness of the soil strata (ARCON Design Build plc, 2018). The SPT-N value was shown that the study area is composed of sand soil with small content of gravel. Furthermore, the study area comprises of loose to dense sandy soil. 


\subsubsection{Equivalent Site Response Analysis (ELA)}

The ELA is an approximation method in which non-linear properties of soil is modeled in terms of equivalent linear soil properties (Kramer 1996; Hashash et al. 2020). The ELA uses the same stiffness and damping properties at the frequency domain for the entire duration of the acceleration time series. ELA is carried out to estimate the seismic wave propagation from bedrock to ground surface. The seismic wave propagation is estimated by the ground motion parameters using peak ground acceleration (PGA), 5\% damped spectral acceleration (SA) and maximum strain (\%) (Kramer 1996; Yoshida et al. 2001; Eker et al. 2015). The detail discussion of the ground motion parameters are given as follows.

Peak ground acceleration (PGA): This is the most direct ground motion intensity measures in which the maximum absolute value of acceleration is measured from the acceleration time series (Kramer 1996; Carlton 2014).

Spectral acceleration $(\boldsymbol{S A})$ : It is measures the maximum response spectrum of the ground motion (Kramer 1996; Yoshida 2015).

Maximum strain (\%): It is a maximum absolute value of shear strain of the ground motion (Kramer 1996; Kavazanjian et al. 1997; Yoshida 2015).

The designs of earthquake ground motions are essential for the input motion and material properties. The recorded time history motion is necessary for the input motion, and thus selected from the recorded ground motion. The recorded ground motion has source, magnitude, local site conditions and style of faulting information (Kramer 1996). For this study, the Pacific Earthquake Engineering Research Center (PEER) database (http://peer.berkeley.edu) was used. The reason for the use of PEER database (http://peer.berkeley.edu) is due to unavailability of strong ground motion in Ethiopia (Kramer 1996; Yee et al. 2013; Mammo 2015; Alemu et al. 2018).

The argument for the suit of ground motion for the study area is based on the shallow depth earthquake occurrence of Western United States and East African rift System (Kedede and Van Eck 1997; Mammo 2015; Ayele 2017; Alemu et al. 2018). In this study, the Northridge ground motion was selected based on the target response spectrum of region: (i) as per ES EN 
1998:2015, (ii) magnitude range of 4 to 7.2 (Kedede and Van Eck 1997; Wilks et al. 2017; Ayele 2017), (iii) focal depth (source) and path (Carlton and Abrahamson 2014; Ayele 2017), (iv) duration range estimated (Bommer et al. 2009) and (v) Vs30 of $245-365 \mathrm{~m} / \mathrm{s}$ for reference bedrock condition. The record sequence, earthquake name, year, earthquake magnitude, fault type, closest distance and preferred Vs30 of the Northridge motion are given in Table 1.

Table 1 The Northridge ground motions selected for this study (http://peer.berkeley.edu)

\begin{tabular}{|l|l|l|l|l|l|l|}
\hline $\begin{array}{l}\text { Record } \\
\text { Sequence }\end{array}$ & Earthquake name & Year & $\begin{array}{l}\text { Earthquake } \\
\text { Magnitude }\end{array}$ & $\begin{array}{l}\text { Fault } \\
\text { type }\end{array}$ & $\begin{array}{l}\text { Closest } \\
\text { distance }\end{array}$ & $\begin{array}{l}\text { Preferred } \\
\mathbf{V s}^{\mathbf{3 0}}(\mathbf{m} / \mathbf{s})\end{array}$ \\
\hline 1093 & Northridge & 1994 & 6.69 & $\begin{array}{l}\text { Reverse } \\
\text { Fault }\end{array}$ & 78 & 309 \\
\hline
\end{tabular}

The material property (shear modulus (G) and damping (D)) is used to determine the consistency of site response analysis (Carlton and Abrahamson 2014). The study area is dominated by lacustrine deposits, which are composed of cohesionles soils (sandy soils). The DEEPSOIL v.7 program requires $\mathrm{G}$ and $\mathrm{D}$ curve of the site as an input to generate time history parameter. However, site specific G and D curve was not developed for Hawassa town. Therefore, this study used the sandy soil typical curves which are available in the DEEPSOIL V.7 program (Carlton and Abrahamson 2014; Mammo 2015; Alemu et al. 2018; Rahman 2019). On the DEEPSOILV.7 program, the families of normalized shear modulus reduction and damping curves were developed for cohesionless (Seed and Idriss 1970; Seed et al. 1986; Idriss 1990) as shown in Fig.3.

The ELA was conducted at five typical sites out of a total 19 sites of MASW. The recommended effective to maximum shear stress ratio value used for this study is 0.65 (Hashash et al. 2020). DEEPSOIL V.7 program contains a motion tab which can be used to view/process input motions were simulated for the five typical sites. Furthermore, the DEEPSOIL V.7 program will generate peak ground acceleration, spectral acceleration and maximum strain. For this study, the site effects were analyzed using DEEPSOIL V.7 program of ground motion prediction parameters (Table 2). The pressure dependent modified Kondner Zelako (MKZ) soil model and masing 
Re/loading hysteric formulation was used for the prediction of ground motion (Hashash et al. 2020). The pressure dependent modified Kondner Zelako (MKZ) soil model is used to adjust the shape of backbone curve (Konder and Zelasko 1963). The Massing/Reloading model determine the model parameters which most closely match the defined curves (Hashash et al. 2020).

Table: 2 DEEPSOILV.7 program analysis ground motion prediction parameters used for this study (Hashash et al. 2020)

\begin{tabular}{|c|c|}
\hline DEEPSOILV.7 program analysis methods & Ground motion prediction parameters \\
\hline $\begin{array}{l}\text { Analysis method } \\
\checkmark \checkmark \text { Equivalent Linear Response Analysis } \\
\text { (ELA) }\end{array}$ & \multirow{4}{*}{$\begin{array}{l}\text { Peak ground acceleration (PGA) } \\
\text { Spectral acceleration (SA) } \\
\text { Maximum strain }(\%)\end{array}$} \\
\hline $\begin{array}{l}\text { Solution type } \\
\quad \checkmark \quad \text { Frequency Domain (FD) }\end{array}$ & \\
\hline $\begin{array}{l}\text { Soil model } \\
\qquad \quad \text { Pressure Dependent Modified Kondner } \\
\quad \text { Zelasko (MKZ) }\end{array}$ & \\
\hline $\begin{array}{l}\text { Default Hysteretic Re/Unloading Formulation } \\
\checkmark \quad \text { Massing/Reloading }\end{array}$ & \\
\hline
\end{tabular}

\subsubsection{Liquefaction Susceptibility}

All soils are not susceptible to liquefaction during dynamic loading of earthquake (Kramer 1996). The soils susceptible to liquefactions are: (i) loose gravelly soils during severe ground shaking or when the gravel layer is confined by an impervious layer (Seed 1968; Ishihara 1985; Andrus et al. 1991), (ii) fine sands (Tsuchida 1970 ; Rahman and Siddiqua 2017), (iii) clay- or silt-size materials having a low plasticity index value (Ishihara 1985; Rahman and Siddiqua 2017), (iv) nonplastic and low plasticity silts, despite having their grain size distribution curves outside of Tsuchida's (1970) boundaries for soils (Walker and Steward 1989). 

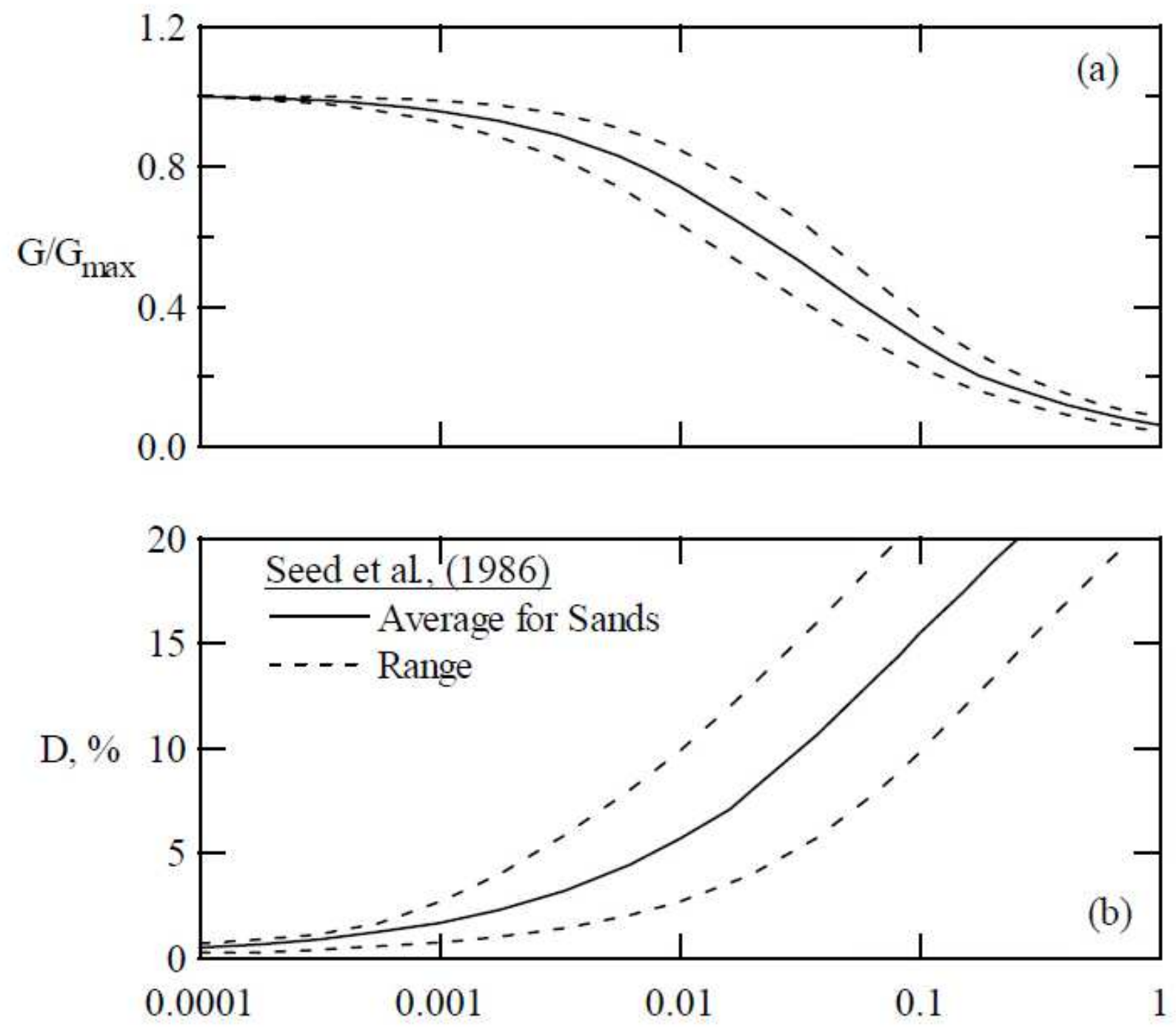

Shear strain $(\%)$

Fig. 3 a) Normalized modulus reduction (G/Gmax) and b) material damping (D) curve (Seed et al 1986 and later modified by Darendeli 2001

The main important factor at a site in any liquefaction evaluation is assessing whether or not the potential for liquefaction exists. For this purpose, the liquefaction screening criteria with in view of liquefaction susceptibility is used according to Dobry and Ladd (1980). The screening criteria used for the liquefaction susceptibility of study area are: (i) geological criteria (groundwater depth, geologic age and origin) (Kavazanjian et al. 1997) and (ii) compositional criteria (grain size, gradation and shape) (Kavazanjian et al. 1997). 
Compositional criteria: The compositional characteristics associated with high volume change potential tend to be associated with high liquefaction susceptibility depends on the particle size, shape and gradation soil (Kramer 1996). Seed et al. (2003) showed that soils are liquefiable when the fraction of the fine (FC) less than 35\%. Tsuchida (1970) summarized the results of sieve analyses performed on a number of different soils that were known to have liquefied or not to have liquefied during earthquakes. He was proposed ranges of grain size (sands and silty sands) curves separating liquefiable and non-liquefiable soils (Fig. 4). The area within the two inner curves represent sands and silty sands, the soils with the lowest resistance to liquefaction. A soil with a gradation curve falling in the zones between the outer and inner curves is less likely to liquefy.

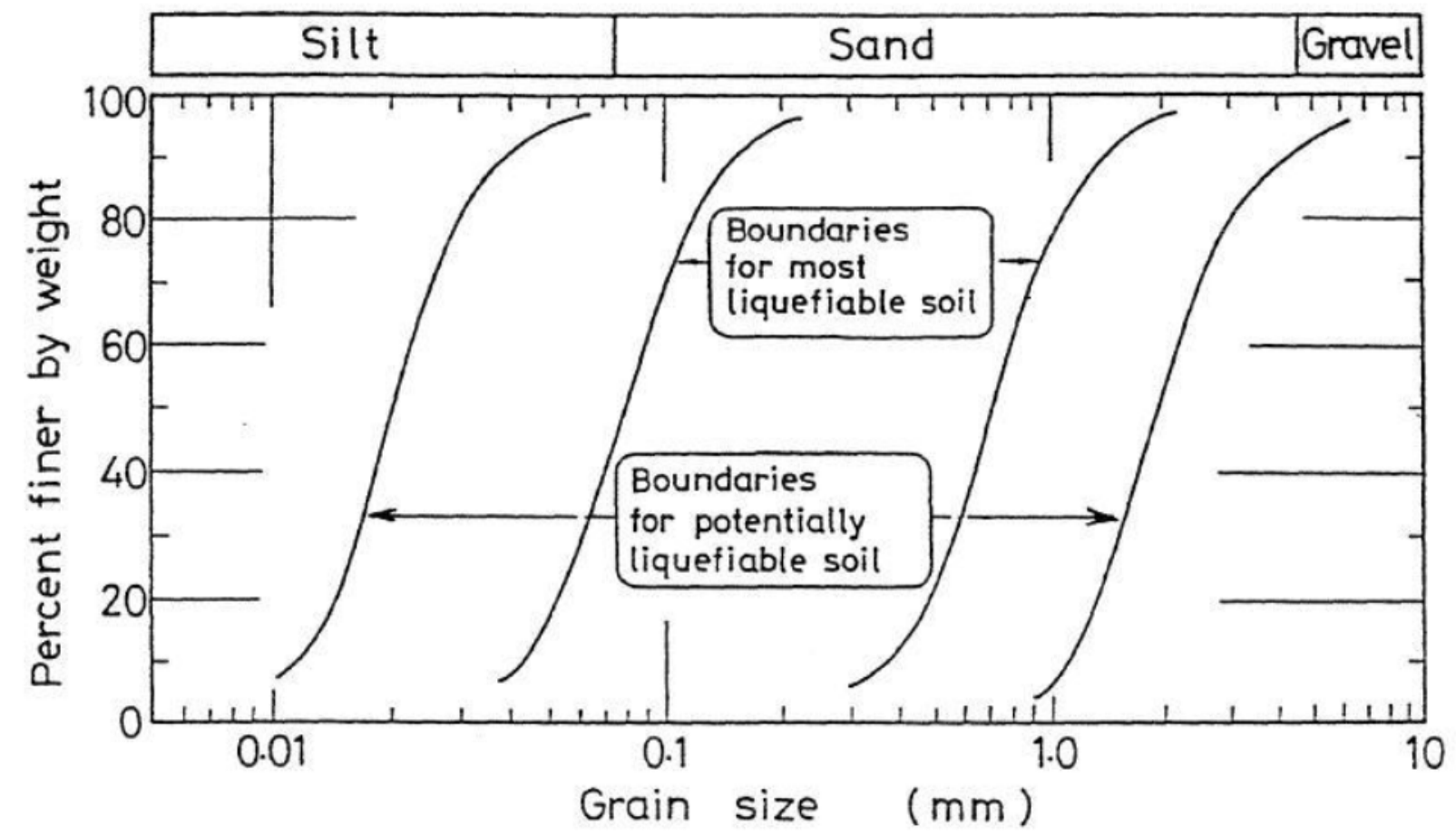

Fig.4 Limits in the gradation curves separating liquefiable and nonliquefiable soils (Tsuchida, 1970)

Geological criteria: Geologic processes that sort soils into uniform grain size distributions and deposit them in loose states produce soil deposits with high liquefaction susceptibility (Kramer 1996). Furthermore, the soil liquefaction susceptibility depends on the age of the deposits and the depth of the static groundwater table (Youd and Hoose 1977; Youd and Perkins 1987). The age of the deposit is an important factor to consider when assessing liquefaction susceptibility. 
Young Holocene sediments in particular site are susceptible to liquefaction (Youd and Hoose 1977; Youd and Perkins 1987). The older soil deposits are less susceptible to liquefaction than newer soil deposits. Hence, soils of Holocene age are more susceptible than soils of Pleistocene age (Kramer 1996). Liquefaction of Pre-Pleistocene deposits is rare (Kramer 1996). The study area soil is lacustrine deposits and its age ranges from Holocene to middle Pleistocene (Žáček et al. 2014). The liquefaction wholly occurs only in saturated soils, so the depth to groundwater (either free or perched) influences liquefaction susceptibility (Kramer 1996). Liquefaction susceptibility decreases with increasing groundwater depth and its effects are most commonly observed at sites where groundwater within a few meters of the ground surface. The liquefaction resistance for soils increases with decreasing degree of saturation so that low degrees of saturated cohesionless soil become liquefied only under severe and long duration of earthquake shaking (Sherif et al. 1977).

Historical criteria: Laboratory test results and field case histories indicate that for a given soil initial void ratio or relative density is one of the most important factors controlling liquefaction. Liquefaction occurs principally in saturated clean sands and silty sands having a relative density less than $50 \%$. For dense sands, however, their tendency to dilate during cyclic shearing will generate negative pore water pressures and increase their resistance to shear stress. The lower limit of relative density beyond which liquefaction will not occur is about 75\% (Kramer 1996; Kavazanjian et al. 1997).

\subsubsection{Liquefaction hazard analysis}

The deterministic method is a simplified procedure used for the evaluation of liquefaction hazards. The liquefaction hazard analysis is calculated using cyclic stress ratio (CSR), cyclic resistance ratio (CRR) and factor of safety (FS) (Andrus and Stokoe II 2000; Andrus et al. 2003; Uyanık et al. 2013). The deterministic approach used for the liquefaction potential hazard evaluation of this study is discussed as follows.

Cyclic Stress Ratio (CSR): The CSR of a soil is the average cyclic shear stress $\left(\tau_{a v}\right)$ soils due to cyclic or earthquake loading to the vertical effective stress $(\sigma v)$ acting on the soil layer (Liu et 
al. 2001; Rahman 2019). The CSR induced by an earthquake at a particular depth on the ground is calculated using equation 2 (Seed and Idriss 1971):

$$
C S R=\frac{\tau_{a v}}{\sigma v \cdot}=0.65\left(\frac{P G A_{\max }}{g}\right)\left(\frac{\sigma v}{\sigma v \cdot}\right) r d
$$

where $\tau_{a v}$ average cyclic shear stress is caused by the earthquake and is assumed to be 0.65 of the maximum induced stress, $P G A_{\max }$ is peak horizontal acceleration at the ground surface and is determined from site response analysis, $g$ is acceleration of gravity $\left(9.81 \mathrm{~m} / \mathrm{s}^{2}\right), \sigma v \cdot$ is effective vertical stress at a depth, $\sigma v$ is vertical stress at a depth and $\mathrm{rd}$ is depth reduction factor. The stress reduction coefficient ( $\mathrm{rd}$ ) is a function of site stratigraphy, soil properties and the characteristics of motion excitation. For this study, the rd values were determined using equation 3 (Iwasak 1986):

$$
r d=1-0.015 z
$$

Where rd is stress reduction coefficient and $\mathrm{z}$ is a depth

Cyclic Resistance Ratio (CRR): The cyclic resistance is the resistance of soil during earthquake. The CRR of soil is determined using the relationship between measured shear wave velocities (Vs1), stress-corrected shear wave velocity $\left(\mathrm{V}_{\mathrm{s} 1}^{*}\right)$ and magnitude scaling factor (MSF). The Hawassa town is comprises of uncommented Holocene to middle Pleistocene sandy soils. Based on this scenarios, the suggested CRR-Vs1 based calculation as given in equation 4 were used (Andrus and Stokoe II 1997; Andrus and Stokoe II 2000; Youd et al. 2001; Uyan1k 2002; Uyanık and Taktak 2009):

$$
C R R=0.022\left(\frac{V s 1}{100}\right)^{2}+2.8\left(\frac{1}{V_{s 1}^{*}-V s 1}-\frac{1}{V_{s 1}^{*}}\right) M S F
$$

Where $V_{S 1}^{*}$ is limiting upper value for cyclic liquefaction occurrence, MSF is magnitude scaling factor to account for the effect of earthquake magnitude. $V_{s 1}^{*}$ is related to average fines content (FC) and can be expressed by equation 5a, $5 \mathrm{~b}$ and $5 \mathrm{c}$ :

$\mathrm{V}_{\mathrm{s} 1}^{*}=250$ for sands with $\mathrm{FC} \leq 5 \%$

$\mathrm{V}_{\mathrm{s} 1}^{*}=215-0.5(\mathrm{FC}-5) \mathrm{m} / \mathrm{s}, \quad$ for sands with $5<\mathrm{FC}<35 \% \quad 5 \mathrm{~b}$

$\mathrm{V}_{\mathrm{s} 1}^{*}=200 \mathrm{~m} / \mathrm{s}, \quad$ for sands and silts with $\mathrm{FC} \geq 35 \% \quad 5 c$ 
Where $\mathrm{FC}=$ average fines content in percent by mass.

The shear wave velocity (Vs) of the soil can be measured using multichannel analysis of surface waves (MASW). In the present study, the stress-corrected shear wave velocity (Vs1) is calculated using equation 6 (Sykora 1987; Robertson et al.1992; Uyanık et al. 2013):

$$
V s 1=V s\left(\frac{p a}{\sigma v}\right)^{0.25}
$$

Where Vs1 stress-corrected shear wave velocity $(\mathrm{m} / \mathrm{s})$, Vs is measured shear wave velocity $(\mathrm{m} / \mathrm{s}), \mathrm{Pa}$ is $100 \mathrm{kN} / \mathrm{m}^{2}$ reference stress or atmospheric pressure and $\sigma v \cdot$ is effective vertical stress $\left(\mathrm{kN} / \mathrm{m}^{2}\right)$.

The MSF is used to adjust CRR for the earthquake moment magnitude greater or less than 7.5. Wilks et al (2017) and Ayele (2017) have suggested that earthquake moment magnitude of the study area was occurred in the past were less than 7.5. Therefore, Andrus and Stokoe II (1997, 2000) relationship was used to calculate the MSF for this study. The MSF is given using equation 7:

$$
M S F=\left(\frac{M w}{7.5}\right)^{n}
$$

Where MSF is magnitude scaling factor, Mw is moment magnitude and $\mathrm{n}$ is the standard depends on the amount of earthquake moment magnitude. Andrus and Stokoe II (1997) determined the upper limit of $\mathrm{n}$ for the equation 7 as -3.3 for $\mathrm{Mw}<7.5$ and later the standard values of $\mathrm{n}=-3.3$ for $\mathrm{Mw}<7.5$ and $\mathrm{n}=-2.56$ for $\mathrm{Mw}>7.5$ was suggested by Andrus and Stokoe II (2000).

Factor of Safety (FS): A factor of safety (FS) is widely used to evaluate liquefaction risk or potential of liquefaction degree. Therefore, the FS is calculated using equation 8 (Andrus and Stokoe II 2000):

$$
F S=\frac{C R R}{C S R}
$$

Where FS is factor of safety, CSR is cyclic stress ratio and CRR is cyclic resistance ratio. In general, when the factor of safety is larger than 1, it is assumed to be no liquefaction occurred and when it is smaller than 1, the liquefaction is assumed to be take place (Seed and Idriss 1982). 


\subsubsection{Liquefaction Potential Index (LPI)}

The LPI is used to assess severity of liquefaction at a surveyed site. The LPI as suggested by Iwasaki et al (1982) supposes that the severity of liquefaction is depends on: (1) the thickness of the liquefied layer; (2) the proximity of the liquefied layer from the ground surface; and (3) the amount by which the factor of safety (FS) is less than 1.0. This study was used Iwasaki et al (1982) proposed equation for LPI which was later summarized by Iwasaki et al (1986), as given in equation 9a, 9b, 9c, 9d and 9e. They are proposed the severe liquefaction could be expected at sites with LPI $>15$ and not expected to occur at sites with LPI $<5$ (Iwasaki et al. 1986) (Table $3)$.

$$
\begin{array}{lr}
\mathrm{LPI}=\int_{0}^{20} \mathrm{~F}(\mathrm{z}) \cdot \mathrm{W}(\mathrm{z}) \mathrm{dz} & 9 \mathrm{a} \\
\mathrm{F}(\mathrm{z})=1-\mathrm{FS} \quad \text { for } \mathrm{FS}<1 & 9 \mathrm{~b} \\
\mathrm{~F}(\mathrm{z})=0 \text { for } \mathrm{FS} \geq 1 & 9 c \\
W(z)=10-0.5 z \text { for } Z<20 m & 9 d \\
\mathrm{~W}(\mathrm{z})=0 \text { for } \mathrm{Z}>20 m & 9 e
\end{array}
$$

Where $\mathrm{z}$ is depth of the midpoint of the soil layer (0 to $20 \mathrm{~m}), \mathrm{dz}$ is differential increment of depth $\mathrm{w}(\mathrm{z})$ is the weighting factor and $\mathrm{F}(\mathrm{z})$ is the severity factor.

Alternatively, Iwasaki et al (1986) suggested discrete liquefaction potential index equation for severity evaluation of site liquefaction, as given in equation 10a, 10b, 10c, 10d and 10e:

$\begin{array}{rlr}\mathrm{LPI} & =\sum_{\mathrm{i}=1}^{\mathrm{n}} \mathrm{WiFSiHi} & 10 \mathrm{a} \\ \mathrm{FSi} & =1-\mathrm{FSi} \quad \text { for FSi }<1 & 10 \mathrm{~b} \\ \mathrm{FSi} & =0 \text { for } \mathrm{FSi} \geq 1 & 10 \mathrm{c} \\ \mathrm{Wi} & =10-0.5 \mathrm{zi} \text { for } \mathrm{z}<20 m & 10 d \\ \mathrm{Wi} & =0 \text { for } \mathrm{z}>20 m & 10 e\end{array}$

Where Wi is weighting factor soil layer, FSi is safety factor of soil layer, $\mathrm{Hi}$ is thickness of the soil layers (m), $\mathrm{n}$ is number of layers and zi is the depth of soil layer (m) 
Table: 3 Liquefaction potential categories based on LPI (Iwasaki et al. 1982)

\begin{tabular}{|l|l|}
\hline LPI & Liquefaction potential category \\
\hline 0 & Very low \\
\hline $0<\mathrm{LPI} \leq 5$ & Low \\
\hline $5<\mathrm{LPI} \leq 15$ & High \\
\hline LPI $>15$ & Very high \\
\hline
\end{tabular}

\subsubsection{Probability of Liquefaction (PL)}

The PL is used to determine the probability of liquefaction at each site depending on a calculated factor of safety. Juang et al (2003) proposed the following equation for estimating the probability of liquefaction as given in equation 11. This equation ranges from zero to one as a function of FS (Table 4).

$P L=\frac{1}{1+\left(\frac{F S}{0.96}\right)^{4.5}}$

Where PL is probability of liquefaction and FS is factor of safety

Table: 4 the proposed classification of the probability of liquefaction (Chen and Juang 2000)

\begin{tabular}{|c|c|c|}
\hline $\begin{array}{l}\text { Probability of } \\
\text { liquefaction }(\mathrm{PL}) \text { ranges }\end{array}$ & Description & Factor of safety (FS) \\
\hline $0.85 \leq \mathrm{PL}<1.00$ & Almost certain that it will liquefy & $0.653 \geq \mathrm{FS}>0.000$ \\
\hline $0.65 \leq \mathrm{PL}<0.85$ & Very likely & $0.837 \geq \mathrm{FS}>0.653$ \\
\hline $0.35 \leq \mathrm{PL}<0.65$ & $\begin{array}{l}\text { Liquefaction/non-liquefaction is equally } \\
\text { likely }\end{array}$ & $1.102 \geq \mathrm{FS}>0.837$ \\
\hline $0.15 \leq \mathrm{PL}<0.35$ & Unlikely & $1.411 \geq \mathrm{FS}>1.102$ \\
\hline $0.00 \leq \mathrm{PL}<0.15$ & Almost certain that it will not liquefy & $\infty \geq \mathrm{FS}>1.411$ \\
\hline
\end{tabular}

\subsubsection{Probability of Liquefaction induced ground failure (PG)}

The PG is a parameter that link FS with the risk of liquefaction induced ground failure. PG is required information for making risk-based design decisions. Li et al (2006) proposed the PG near foundation in equation 12 (Table 5): 


$$
\mathrm{PG}=\frac{1}{\left(1+\mathrm{e}^{4.9-0.74 \mathrm{LPI}}\right)}
$$

Where PG is probability of liquefaction induced ground failure, LPI is liquefaction potential index.

Table: 5 Probability of liquefaction-induced ground failure (Li et al. 2006)

\begin{tabular}{|l|l|}
\hline Probability & Description of the risk of liquefaction induced ground failure \\
\hline $0.9>\mathrm{PG}$ & Extremely high to absolutely certain \\
\hline $0.7<\mathrm{PG} \leq 0.9$ & high \\
\hline $0.3<\mathrm{PG} \leq 0.7$ & medium \\
\hline $0.1<\mathrm{PG} \leq 0.3$ & low \\
\hline $0.1 \leq \mathrm{PG}$ & Extremely low to none \\
\hline
\end{tabular}

\section{Results and Discussions}

\subsection{Analysis of site characterization and classification}

For this study, a total of 19 MASW has conducted for the site characterization and classification. The Vs30 was used to characterize and classify the study area according to seismic codes. The Vs30 of the study area ranges from $248.9 \mathrm{~m} / \mathrm{s}$ to $371.3 \mathrm{~m} / \mathrm{s}$ (Table 6). The site class was C and D based on the NEHRP (2015) whereas B and C based on the EC8 (2003). The stratigraphic profiles according to NEHRP (2015) was very dense /soft rock to stiff soil while very dense sand to medium dense sand according to EC8 (2003). The MASW was showed that the 17 sites are belong to D class for NEHRP (2015) and C based on the EC8 (2003) whereas 2 sites was found to be C according to NEHRP (2015) (Fig. 5a) and B based on the EC8 (2003) Fig.5b. The typical grain size analysis curve of the Hawassa town was plotted shows cohessionless soils. The typical grain size analysis curve (Fig.6) of the study area comprises sandy soil. 
Table: 6 The MASW data of the study area

\begin{tabular}{|c|c|c|c|c|}
\hline \multirow{2}{*}{ S.No } & \multirow{2}{*}{ Site code } & \multirow{2}{*}{$\operatorname{Vs30}(\mathbf{m} / \mathbf{s})$} & \multicolumn{2}{|c|}{ Study area site classes } \\
\hline & & & NEHRP (2015) & Eurocode 8 (2003) \\
\hline 1 & 1 & 362.3 & $\mathrm{C}$ & B \\
\hline 2 & 2 & 350 & $\mathrm{D}$ & $\mathrm{C}$ \\
\hline 3 & 3 & 301.1 & $\mathrm{D}$ & $\mathrm{C}$ \\
\hline 4 & 4 & 269.3 & $\mathrm{D}$ & $\mathrm{C}$ \\
\hline 5 & 5 & 371.3 & $\mathrm{C}$ & $\mathrm{B}$ \\
\hline 6 & 6 & 301.1 & $\mathrm{D}$ & $\mathrm{C}$ \\
\hline 7 & 7 & 345.5 & $\mathrm{D}$ & $\mathrm{C}$ \\
\hline 8 & 8 & 265.8 & $\mathrm{D}$ & $\mathrm{C}$ \\
\hline 9 & 9 & 260.7 & $\mathrm{D}$ & $\mathrm{C}$ \\
\hline 10 & 10 & 267.9 & $\mathrm{D}$ & $\mathrm{C}$ \\
\hline 11 & 11 & 270.5 & $\mathrm{D}$ & $\mathrm{C}$ \\
\hline 12 & 12 & 275.7 & $\mathrm{D}$ & $\mathrm{C}$ \\
\hline 13 & 13 & 355.9 & $\mathrm{D}$ & $\mathrm{C}$ \\
\hline 14 & 14 & 356.9 & D & $\mathrm{C}$ \\
\hline 15 & 15 & 270.4 & $\mathrm{D}$ & $\mathrm{C}$ \\
\hline 16 & 16 & 347.9 & $\mathrm{D}$ & $\mathrm{C}$ \\
\hline 17 & 17 & 266.9 & $\mathrm{D}$ & $\mathrm{C}$ \\
\hline 18 & 18 & 264.7 & $\mathrm{D}$ & $\mathrm{C}$ \\
\hline 19 & 19 & 248.9 & $\mathrm{D}$ & $\mathrm{C}$ \\
\hline
\end{tabular}




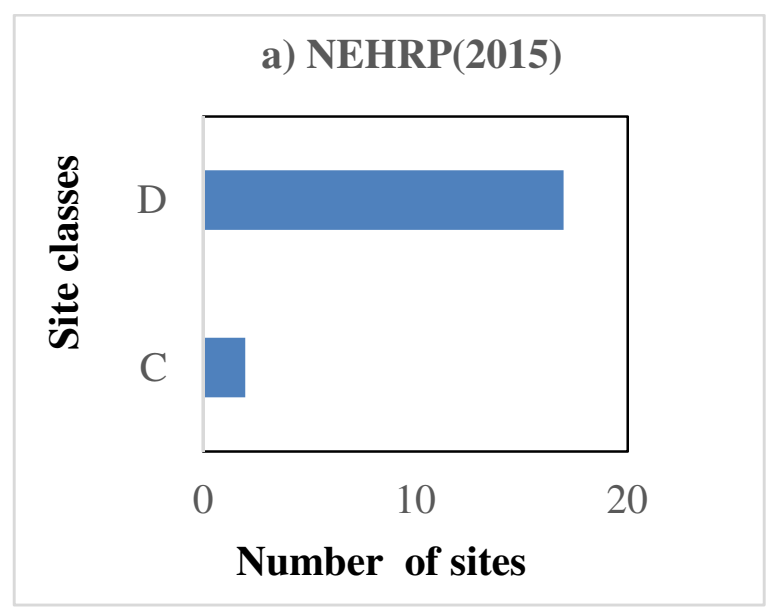

Fig. 5a Histogram of site classification

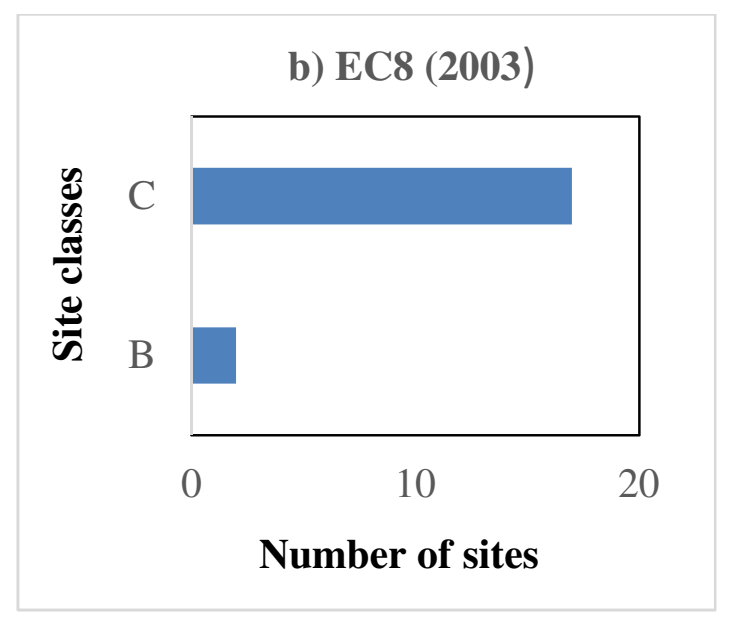

Fig. 5b Histogram of site classification

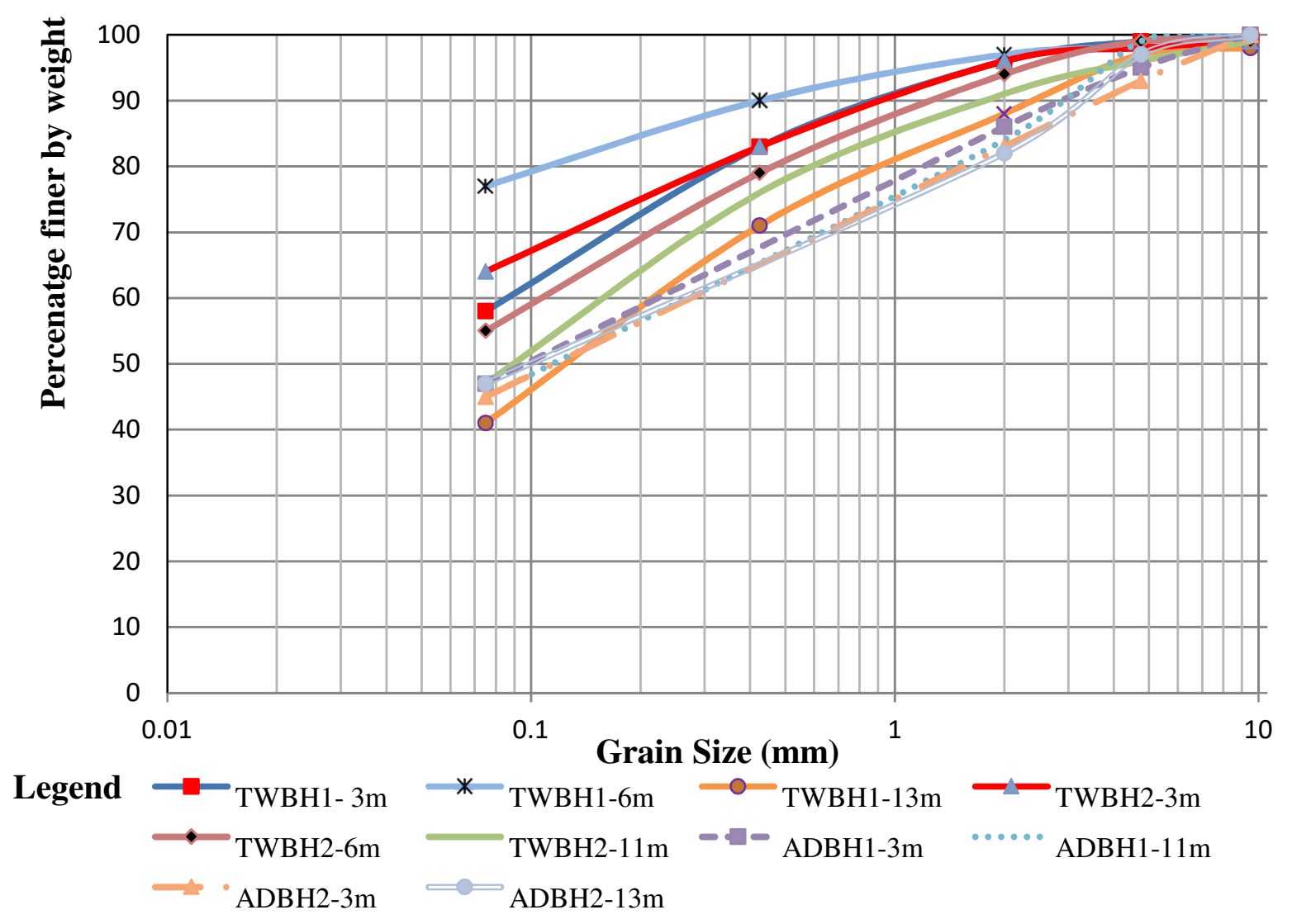

Fig. 6 Grain size curve of the study area 


\subsection{Analysis of ELA}

Ground motion prediction parameter was determined using PGA (g) and SA (g) at the typical five sites. For this study, Northridge ground motion with moment of magnitude 6.63 from PEER data base was used as an input to simulate the propagation of seismic wave from engineering bedrock to ground surface. The variation of PGA (g), maximum strain $(\%)$ and SA $(\mathrm{g})$ at different depths for the typical five sites were generated and its detailed analysis is given as follows.

Analysis of PGA for site 1, site 2, site 3, site 4 and site 5: For this study, ELA was used to predict earthquake motion in Hawassa town. The PGA (g) values at the surface were found to be (Fig. 7): (i) 0.281 for the site 1, (ii) 0.234 for the site 2, (iii) 0.203 for the site 3, (iv) 0.166 for the site 4 and (v) 0.18 for the site 5 . The results showed that the high PGA (g) value was observed at the site 1. Whilst the lowest PGA (g) values were observed at the site 4. In addition, the PGA (g) for site 1 , site 2 , site 3 , site 4 and site 5 was very low at the depth of $5 \mathrm{~m}$ to $11 \mathrm{~m}$. However, PGA (g) was found high at a depth of $0-5 \mathrm{~m}$ for the typical five typical sites (Fig.7). The depths versus PGA (g) plot for the five typical sites were followed similar trends. The typical fives sites in the study area was showed high amplification from engineering bedrock to a surface for the input motion.

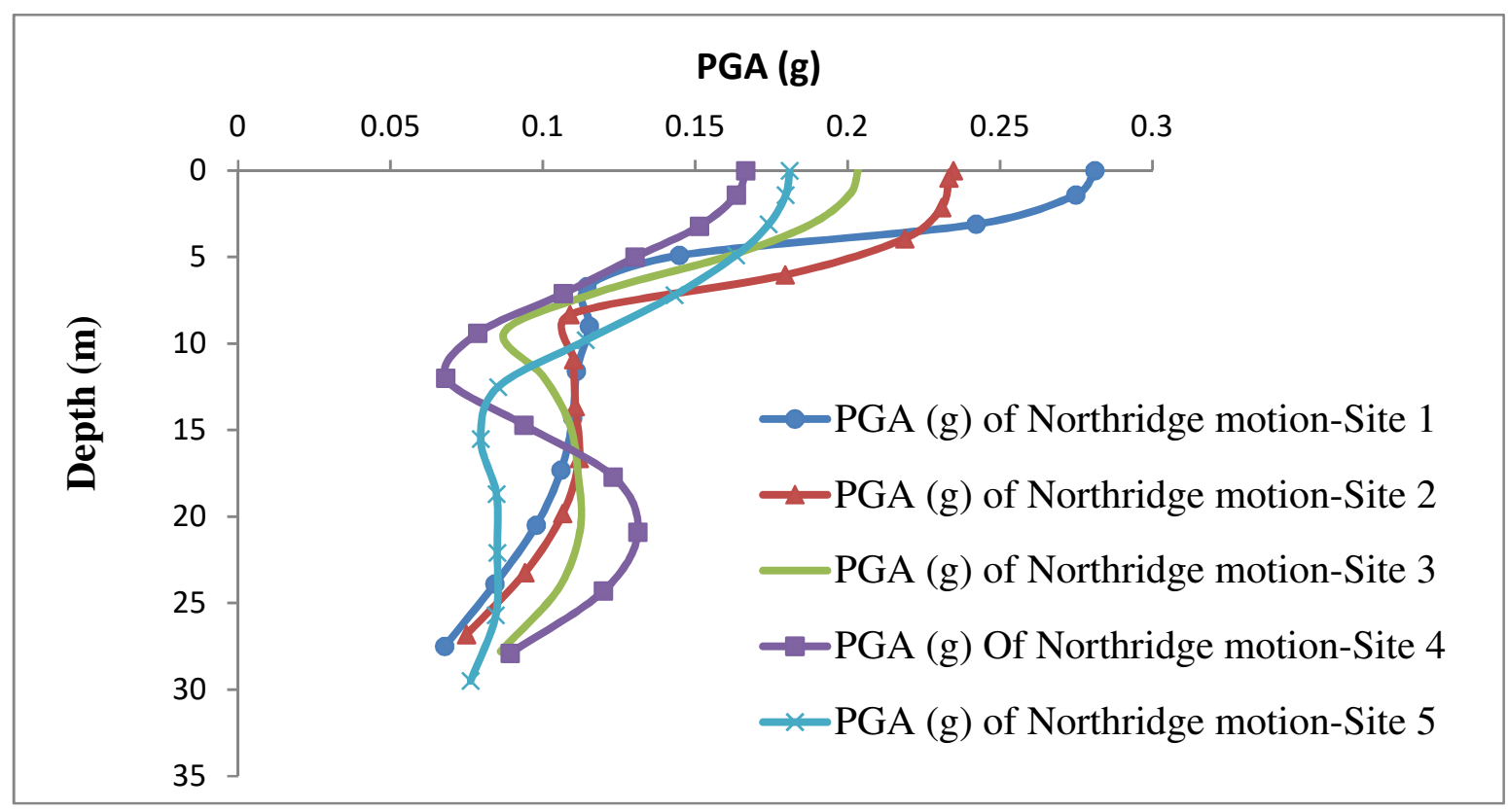

Fig.7 PGA (g) for the site 1, site 2, site 3, site 4 and site 5 
Analysis of maximum strain for site 1, site 2, site 3, site 4 and site 5: The maximum strain (\%) for the typical five sites of Hawassa town was indicated that (Fig. 8): (i) at the site 1, the maximum strain (\%) was found to be increases at a depth of $5 \mathrm{~m}$ and then decreasing up to the depth of investigation, (ii) at the site 2 , the maximum strain (\%) was shown to be increase at a depth of $8 \mathrm{~m}$ and then followed the trends of decrease at a depth of $22 \mathrm{~m}$ before increase, (iii) at the site 3, the maximum strain (\%) was increased at a depth of $9 \mathrm{~m}$, decreased at a depth of $23 \mathrm{~m}$ and finally starts to increase at a depth of $28 \mathrm{~m}$, (iv) at the site 4 , the maximum strain (\%) was increased up to depth of $18 \mathrm{~m}$ before to decrease and (v) at the site 5, the maximum strain (\%) was increased up to depth of $10 \mathrm{~m}$ and then it was decreased from a depth $10 \mathrm{~m}$ to $30 \mathrm{~m}$. In addition, high strain was occurred at the site 1 than other typical sites whereas low strain was occurred at the site 5 (Fig.8). The large stress deformation will be expected for the site 1 than the other typical sites for the simulated earthquake ground motion.

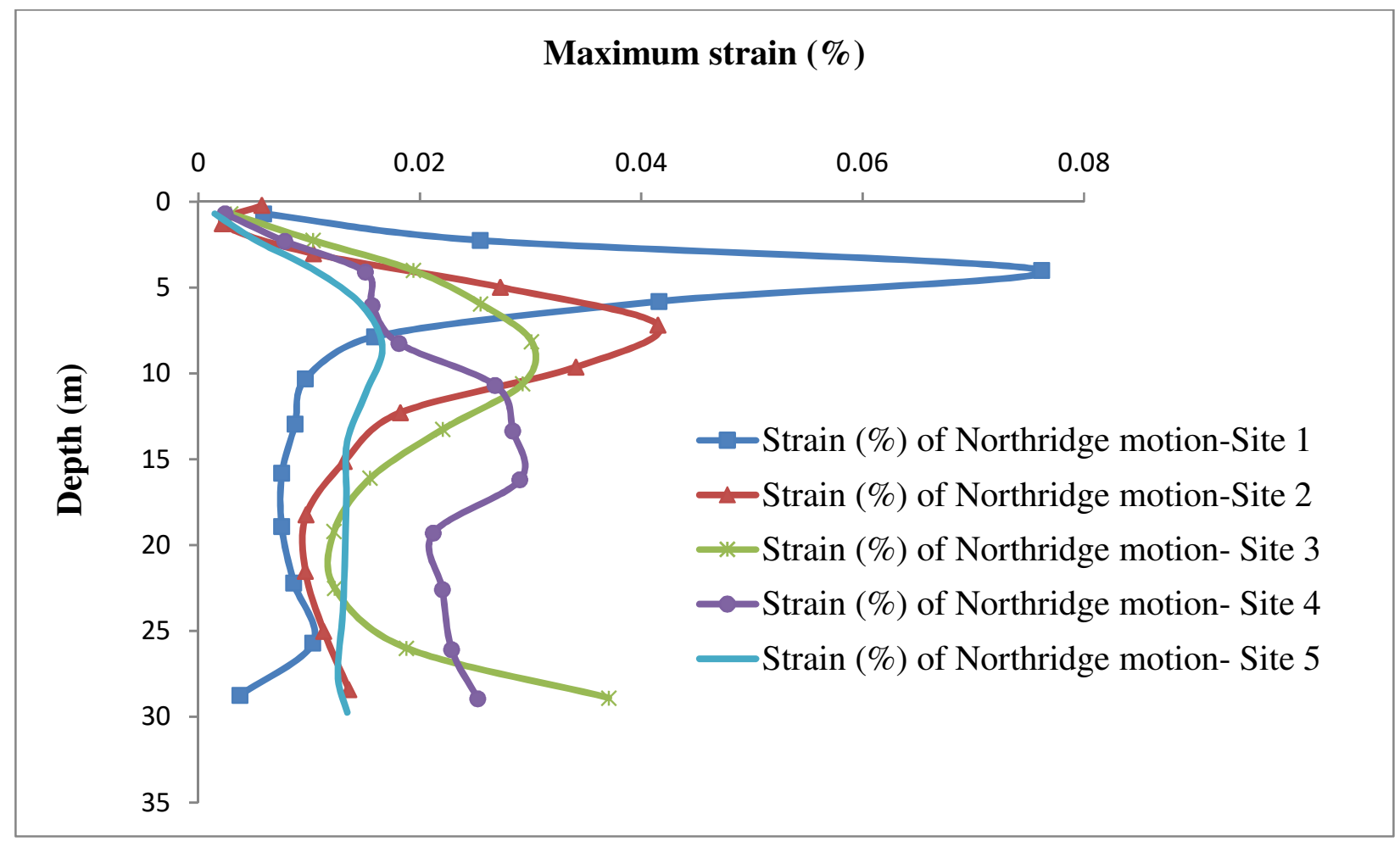

Fig.8 Maximum strain (\%) at the site 1, site 2 site 3 , site 4 and site 5

Analysis of SA for site 1, site 2, site 3, site 4 and site 5: The 5\% damped SA for the typical five sites of Hawassa town were very high at a period from $0.1 \mathrm{sec}$ to $1 \mathrm{sec}$ (Fig.9). At the period $0.1 \mathrm{sec}$ to $1 \mathrm{sec}, 5 \%$ SA of the site 1 , site 2 , site 3 , site 4 and site 5 will be very high for the input 
ground motion. The analysis of the site 1 for 5\% damped SA was found to be 1.2. The value of 5\% damped SA for the site 2 was 0.81 whereas 0.8 for the site 3 . In addition, the value of $5 \%$ damped SA for the site 4 and site 5 were found to be 0.71 and 0.7 respectively. The high value of $5 \%$ damped SA was observed at the site 1 whilst the low value of 5\% damped SA was shown at the site 5. The high value of 5\% damped SA at the site 1 was indicated that there will be high amplification for the earthquake Mw 6.69.

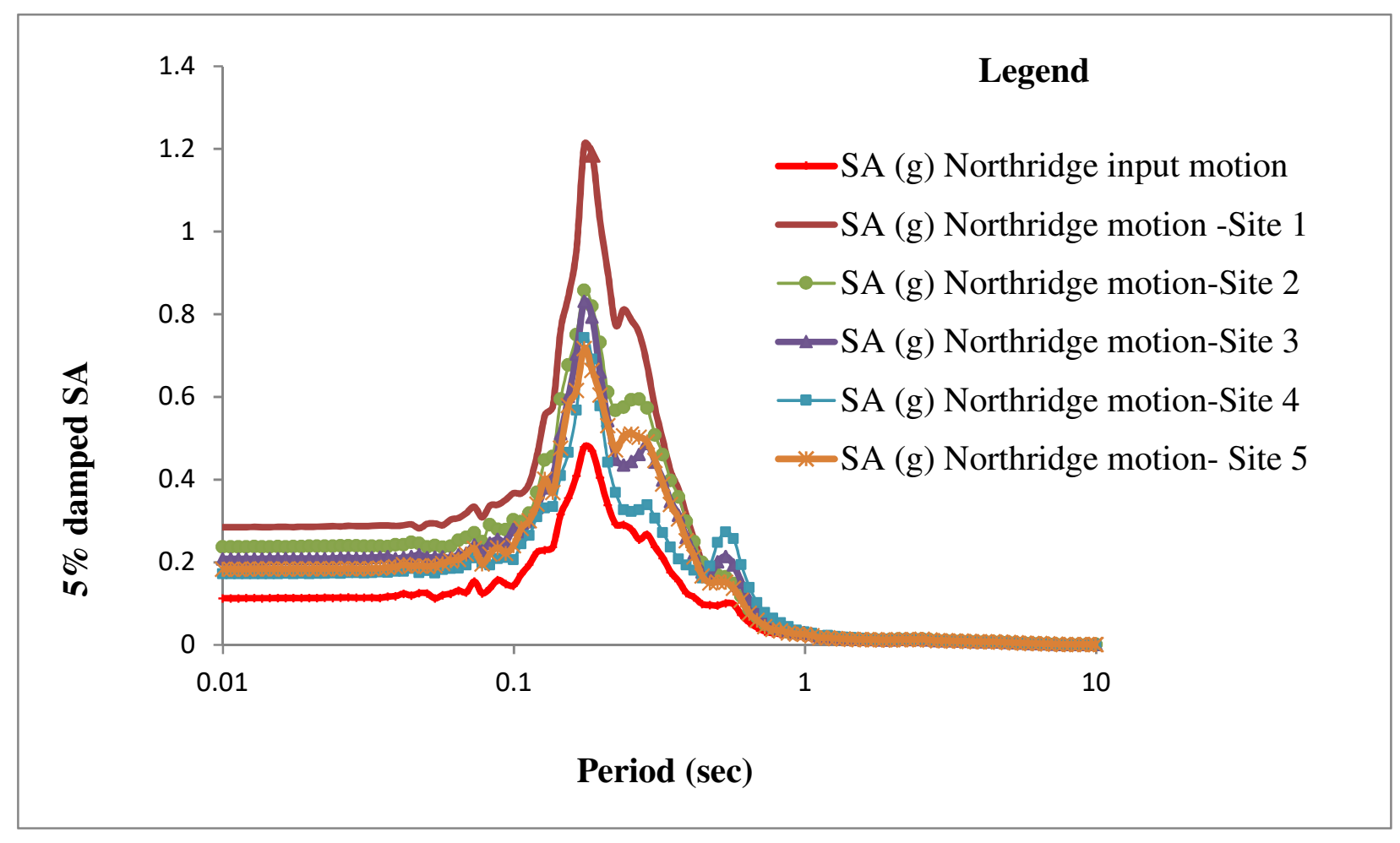

Fig. $95 \%$ damped SA (g) at the site 1, site 2, site 3, site 4 and site 5

\subsection{Analysis of liquefaction susceptibility}

Grain size analysis: The grain size was analyzed to determine the nature of the soil (plastic or non-plastic) by ARCON Design Build plc (2018). The grain size analysis curve reveals grain size of soils. In addition, the grain size curve showed that all the sites are sandy soil. Therefore, sandy soil is susceptible to liquefaction as per the screening criteria of Tsuchida 1970 and Rahman and Siddiqua (2017). Furthermore, the grain size curve showed all the site soils at a depth of $1 \mathrm{~m}$ to $13 \mathrm{~m}$ were fall at the boundaries of most liquefiable and potentially liquefiable soil curves (Fig.10), which was supported by the preliminary screening liquefaction susceptibility criteria of Tsuchida (1970). 


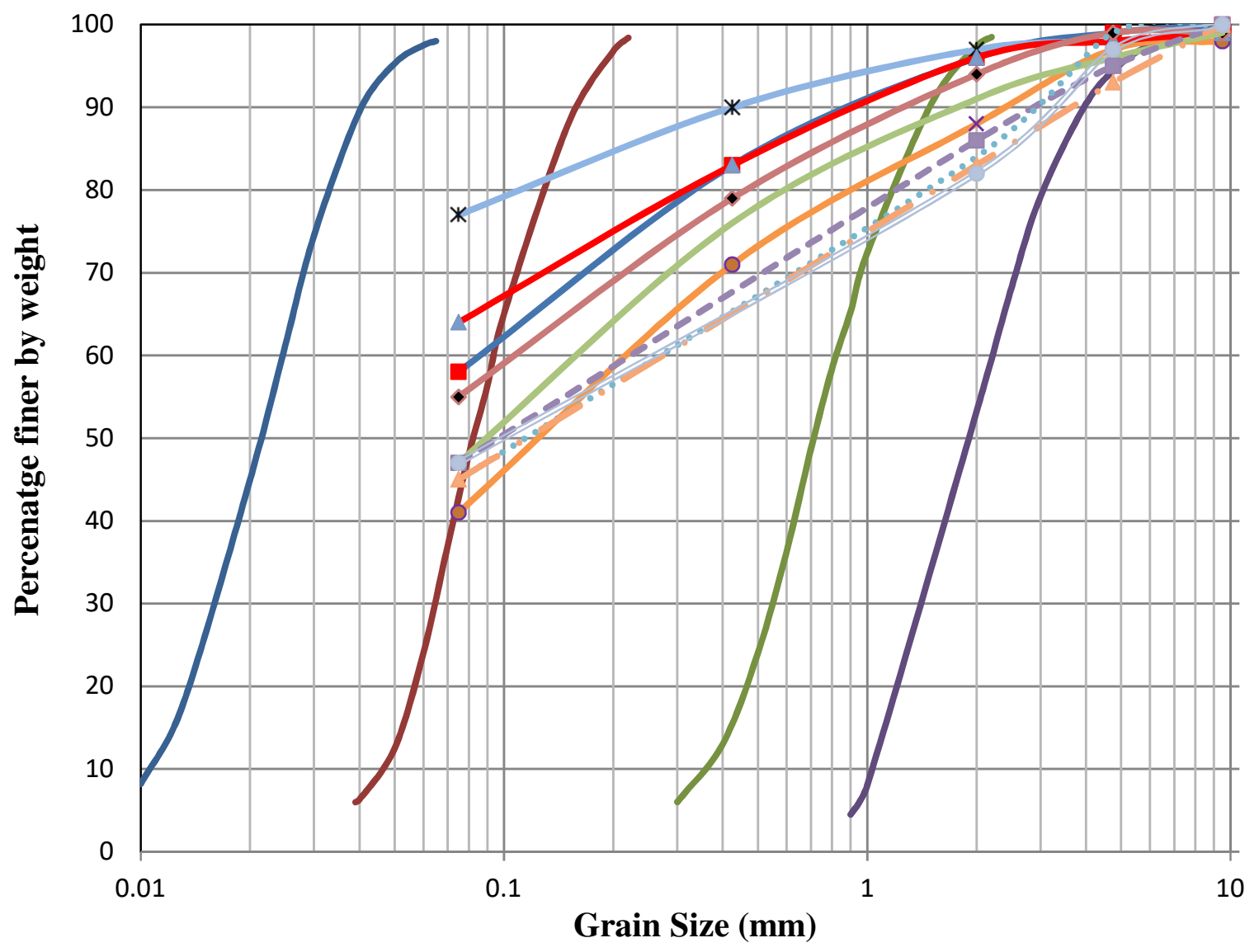

Legend

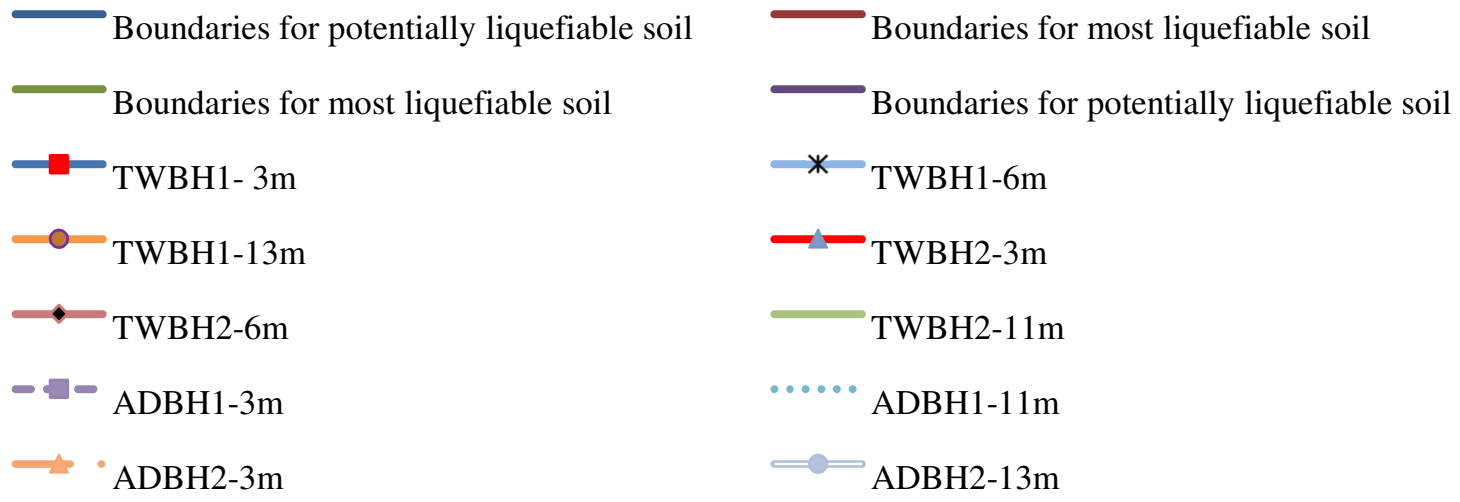

Fig. 10 Grain size distribution curve of sandy soil.

Relative density analysis: The study area comprises of sandy soil and its relative density is less than 50\% based on the data of ARCON Design Build plc (2018). The susceptibility of liquefaction is expected at the sandy soil, which was supported by the screening criteria of 
Kramer (1996) and Kavazanjian et al. (1997). This is due to the fact that the soil which has less relative density is more susceptible for liquefaction than high relative density.

Degree of saturation: The liquefaction occurs in saturated cohessionless soil. The liquefaction decreases with increasing groundwater depth. The depth of groundwater in the study area ranges from $2 \mathrm{~m}$ to $56 \mathrm{~m}$ (SDCSE 2019). Therefore, the susceptibility of liquefaction is expected as per the screening criteria of Kramer (1996) and Kavazanjian et al. (1997).

Age of the soil: The age of soil in the study area ranges from Holocene to middle Pleistocene as described by Žáček et al. (2014). The degree of liquefaction susceptibility is more in Holocene soil than Pleistocene soil. Therefore, the likelihood of liquefaction susceptibility in the study area is varies from moderate to low as per screening criteria of Youd and Perkins (1987).

\subsection{Analysis from CSR, CRR and FS using Vs}

For this study, the Vs using MASW methods were measured. Then, the CSR, CRR and FS were determined using Vs values to evaluate liquefaction potential at the typical five site of Hawassa town. The liquefaction potential for the typical sites was simulated with Mw 6.69 of Northridge motion. The detailed analysis of the typical five sites is given below.

Analysis for site 1: It was evident that the groundwater level (GWT) from the borehole data was observed at a depth of $2 \mathrm{~m}$. The Vs, CSR, CRR and FS were determined up to a depth of 30m. The plots of Vs, CSR, CRR and FS versus depth are shown in Fig.11. The Vs for this site ranges from $168 \mathrm{~m} / / \mathrm{s}$ to $542 \mathrm{~m} / \mathrm{s}$. The $\mathrm{V}_{\mathrm{S}}$ was shown that there are decreases up to $5 \mathrm{~m}$ before the increase at the depth up to $25 \mathrm{~m}$. The decrease of Vs was revealed at a depth greater than $25 \mathrm{~m}$. CSR value was varies from 1.29 to 1.45. Therefore, the CSR values were greater than FS limit. The value of CRR varies from 0.007334 to 1.755 . The value of CRR was less than FS limit goes to a depth of $9.5 \mathrm{~m}$. Whereas CRR values were greater than FS limit to a depth greater than $11.9 \mathrm{~m}$. The value of FS ranges from 0.00543 to 1.285 . In addition, the FS was less than one from $3 \mathrm{~m}$ to $11.9 \mathrm{~m}$ depth. While the FS was greater than one at a depth starts from $11.9 \mathrm{~m}$ to $30 \mathrm{~m}$. Finally, the CSR, CRR and FS values of the site were shown that liquefaction is expected up to a depth of $11.9 \mathrm{~m}$. 


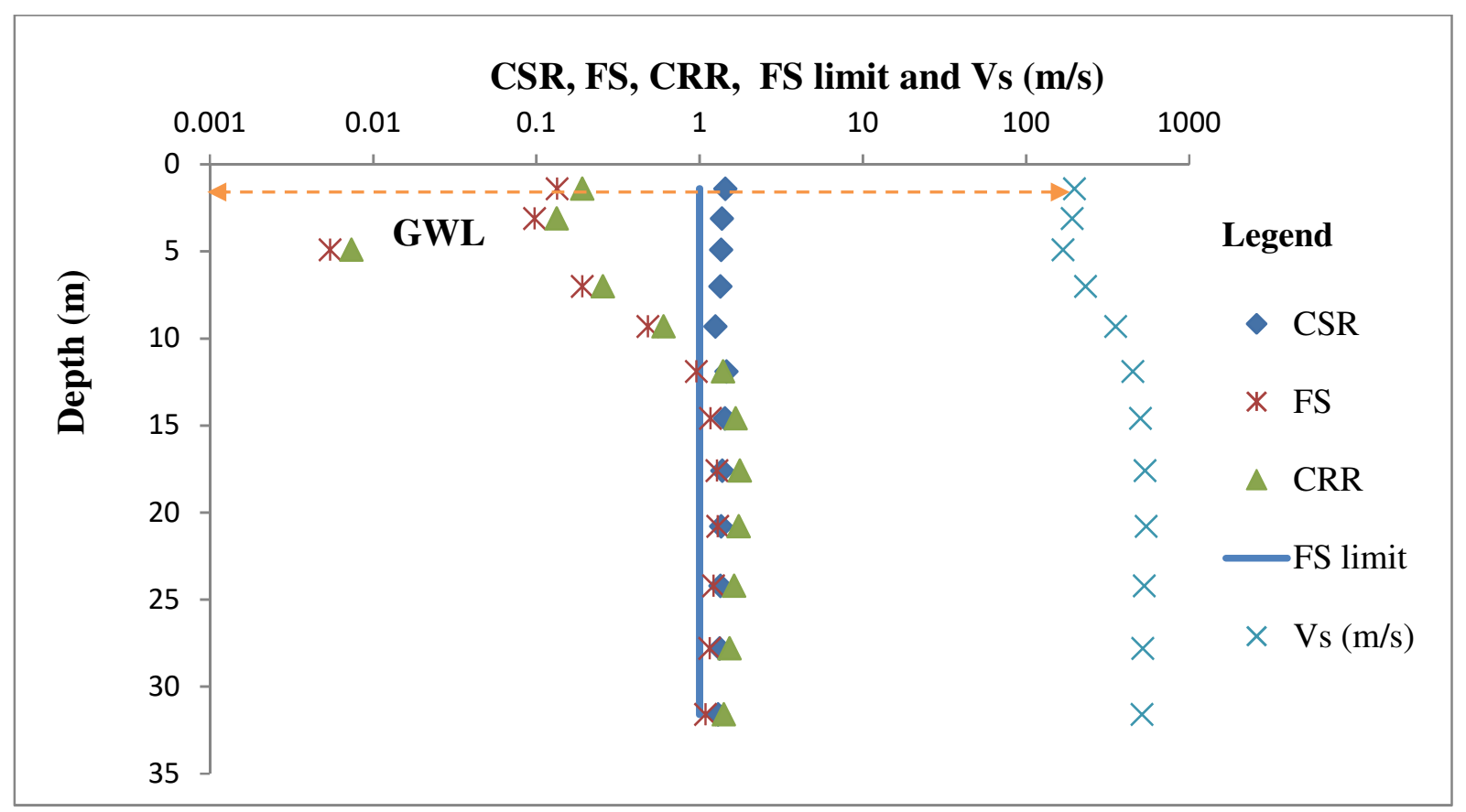

Fig.11 CSR, CRR, FS and FS limit at the site 1

Analysis for site 2: The groundwater level (GWT) from the borehole data was found to be at a depth of $22.5 \mathrm{~m}$. The Vs, CSR, CRR and FS profile plot with a depth is shown at Fig. 12. The Vs was varies from $269 \mathrm{~m} / \mathrm{s}$ to $452 \mathrm{~m} / \mathrm{s}$. The Vs decreases at a depth of $10 \mathrm{~m}$ before starts to increase. The values of CSR vary from 0.00708 to 0.016 . The CRR goes from 0.229 to 1.361 . The FS was greater than unity, and which ranges from 17.38 to 114.29 . According to the values of CSR and CRR, the CSR was less than CRR. As a result, the FS was also greater than one. The values of FS in this site was shown that there is no liquefaction occurrence at the given earthquake motion. 


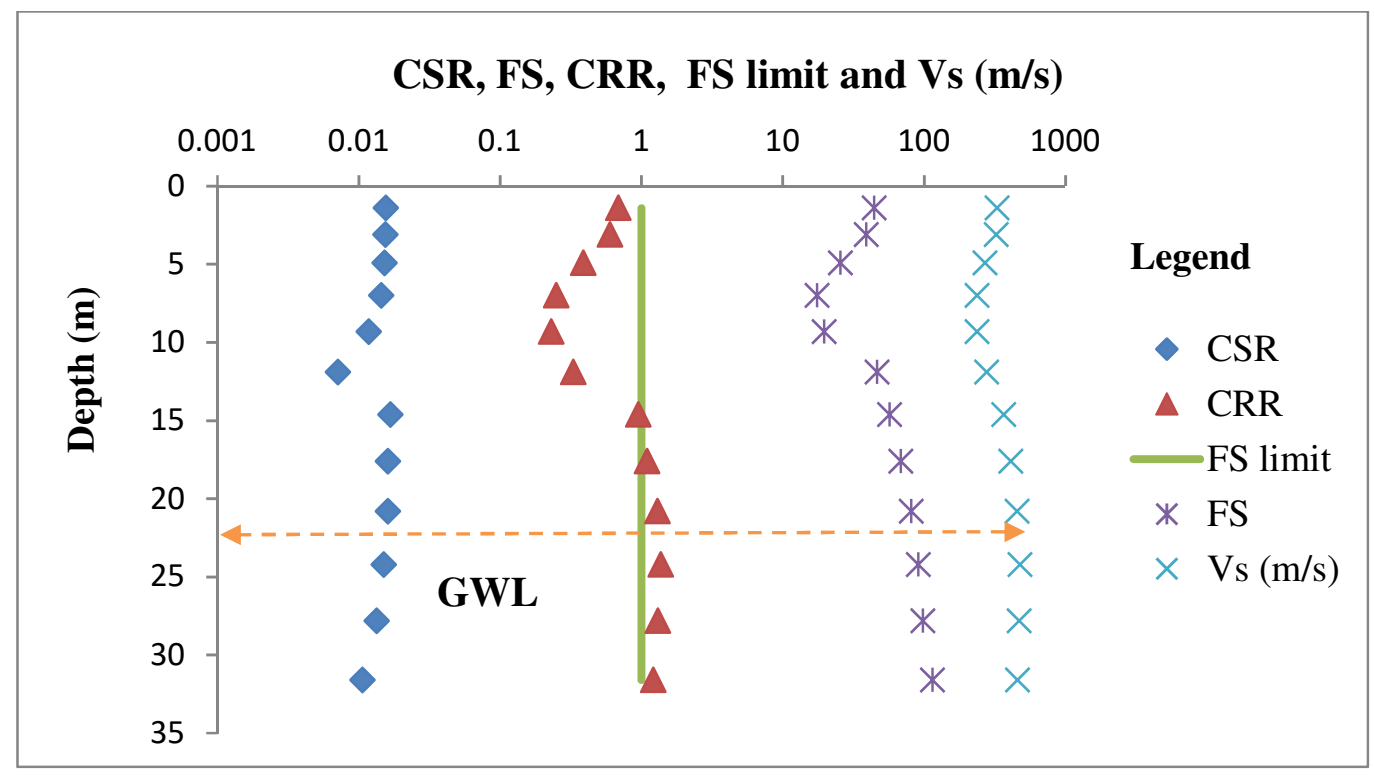

Fig. 12 CSR, CRR, FS and FS limit at the site 2

Analysis for site 3: At this site, the groundwater level (GWL) from the borehole data was revealed at a depth of $27 \mathrm{~m}$. The profile plot of depth versus Vs, CSR, CRR and FS are shown in Fig.13. The Vs varies from $233 \mathrm{~m} / \mathrm{s}$ to $390 \mathrm{~m} / \mathrm{s}$. The analysis of this profile was shown that: (i) the Vs decreases from surface to a depth of $9.5 \mathrm{~m}$, increases at a depth of $11 \mathrm{~m}$ and decreases at a depth of $30 \mathrm{~m}$, (ii) the CSR values was vary from 0.07749 to 0.0165 , (iii) CRR values varies from 0.406 to 1.052 and (iv) FS was ranges from 52.0407 to 63.41. Based on the comparison of CSR, CRR and FS values, CRR was greater than CSR. As a result, the FS was greater than one. FS is greater than unity for this site, and thus indicated that liquefaction is not induced for the given earthquake ground motion. 


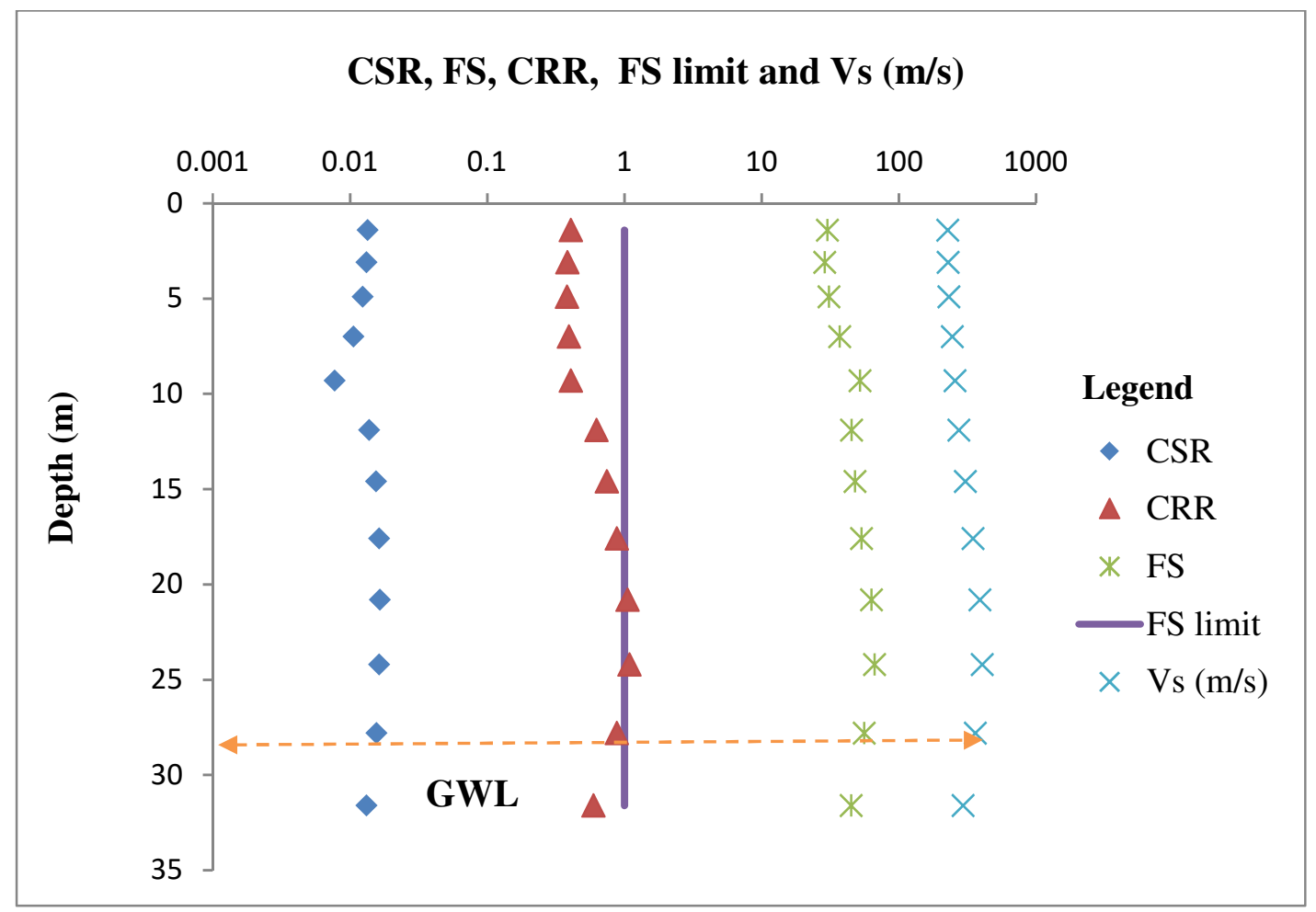

Fig. 13 CSR, CRR, FS and FS limit at the site 3

Analysis for site 4: The depth of groundwater level (GWL) as it was explained from the borehole data was 27.5m. The Vs, CSR, CRR and FS profile versus depth is shown in Fig. 14. The Vs profile varies from $241 \mathrm{~m} / \mathrm{s}$ to $284 \mathrm{~m} / \mathrm{s}$. The Vs was found to be increase at a depth of $9.5 \mathrm{~m}$. After this depth, the Vs were shown trends of decrease or relatively constant up to a terminal depth. The CSR, CRR and FS were shown that: (i) the values of CSR was varies from 0.00442 to 0.0203, (ii) the CRR value were ranges from 0.292 to 0.481 and (ii) FS found to be 23.5 to 66.2. The analysis of CSR, CRR and FS was shown that the CRR values were greater CRR. Due to the larger value of CRR, the FS was found to be greater than unity. The FS was indicated that for this site liquefaction does not exist for the simulated ground motion. 


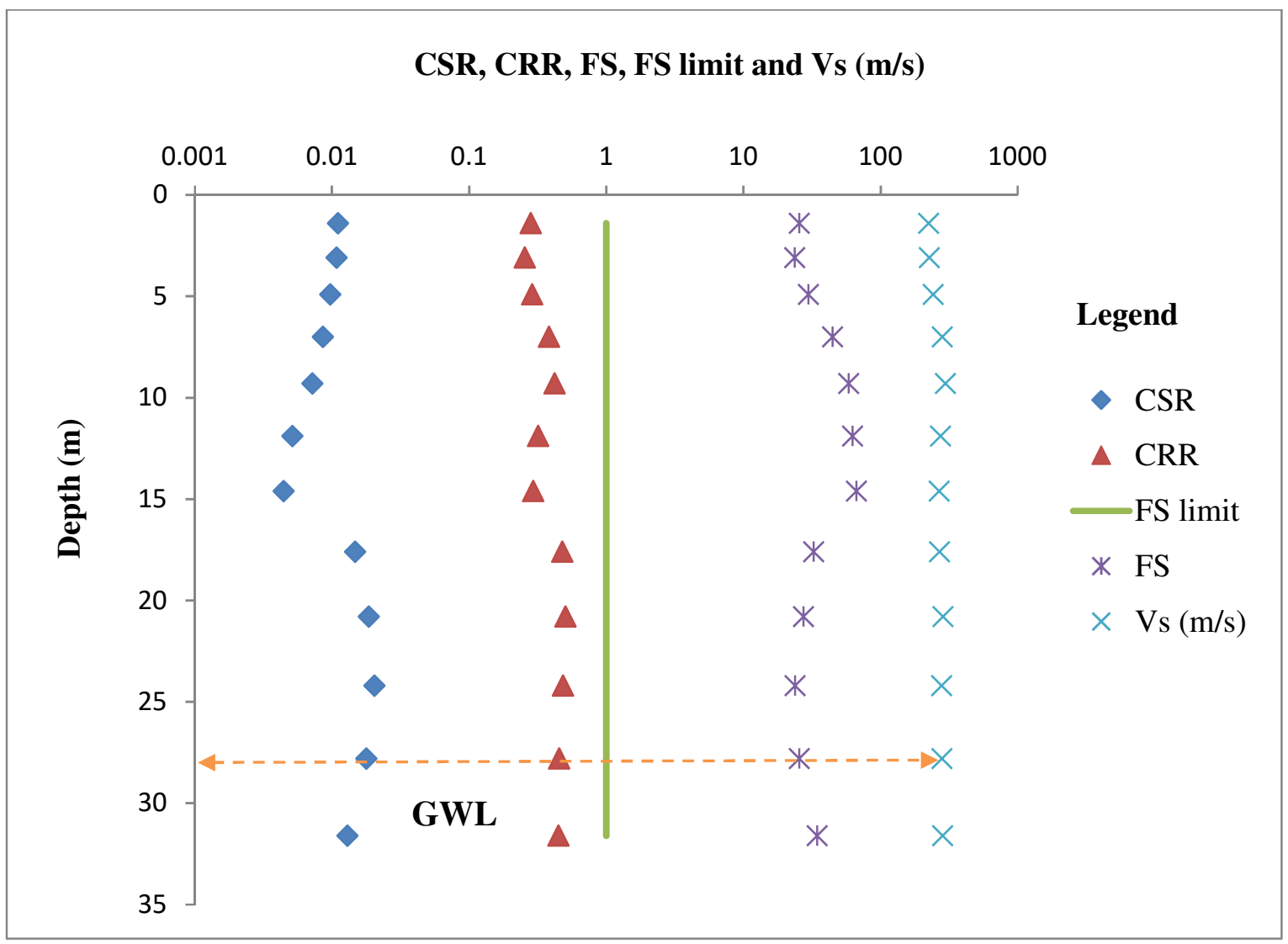

Fig.14 CSR, CRR, FS and FS limit at the site 4

Analysis for site 5: As it was evident from the borehole data on this site, the groundwater level was occurred at a depth of $25 \mathrm{~m}$. The Fig.15 shows plot of depth versus Vs, CSR, CRR and FS values. The Vs value of this site was found to be $291 \mathrm{~m} / \mathrm{s}$ to $444 \mathrm{~m} / \mathrm{s}$. The Vs profile was shown that Vs increase from ground surface to a depth of 30m. The CSR was varies from 0.051 to 0.0123. Whilst the CRR was ranges from 0.423 to 1.26 . The earthquake resistance force was greater than driving cyclic stress for this site. Since the FS was greater than unity as a result the liquefaction is not exist for the given earthquake magnitude. 


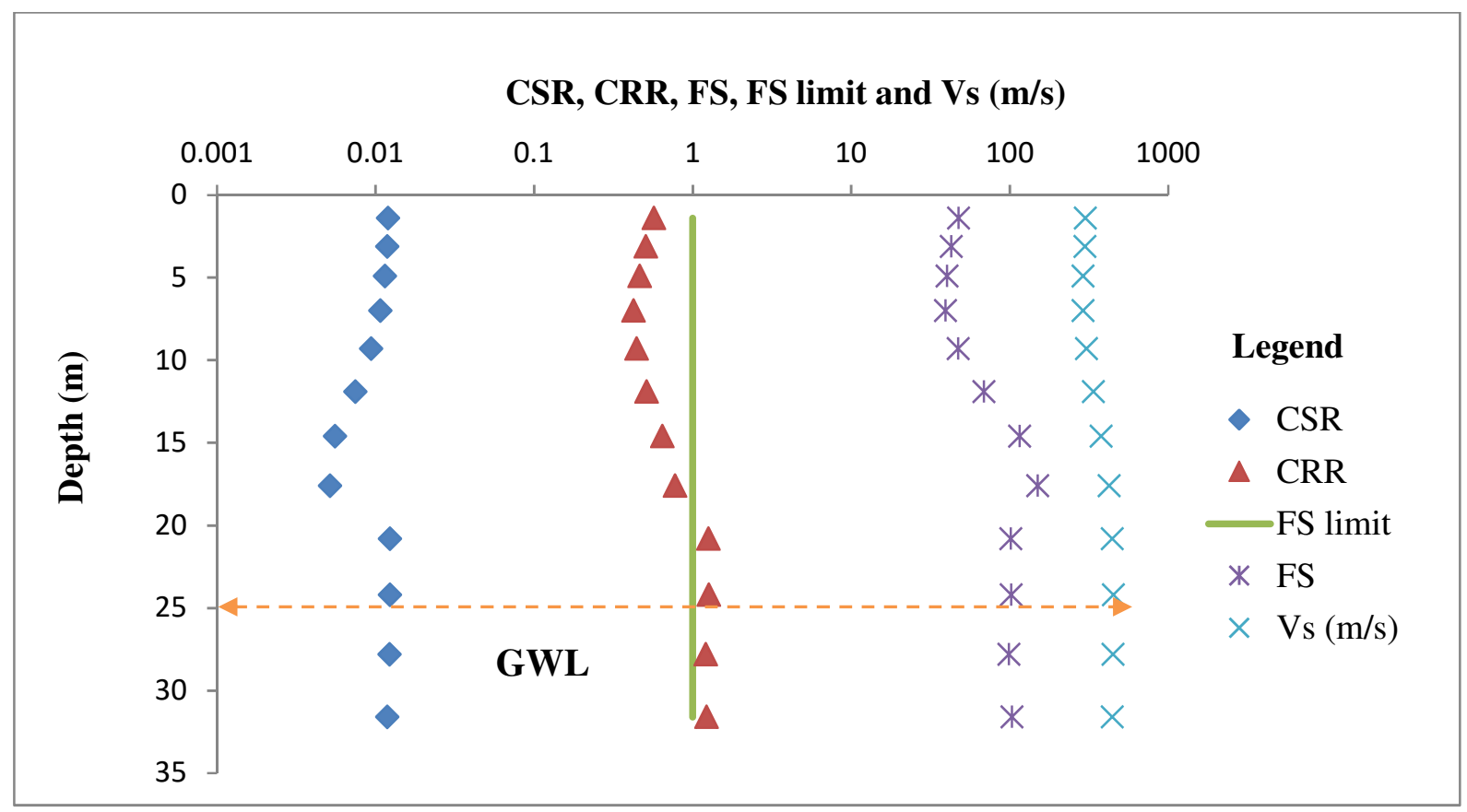

Fig.15 CSR, CRR, FS and FS limit at the site 5

\subsection{Analysis from LPI, PL and PG}

For this study, the LPI, PL and PG were determined for the typical five sites in Hawassa town based on the Vs, CSR, CRR and FS values. The detailed analysis of LPI, PL and PG are given below.

Analysis of site 1, site 2, site 3, site 4 and site 5: The LPI for the typical five sites in Hawassa town was ranges from very high (54.16) to very low (zero). The LPI was found to be very high for site 1 and very low for the site 2 , site 3 , site 4 and site 5 . In addition, the liquefaction potential category for the site 1 was found to be 54.16 and 0 for the site 2 , site 3 , site 4 and site 5 (Table 3). The PL and FS of the site 1 was varies from 0.21 to 1 and 0.00543 to 1.285 respectively. The PL for the site 2, site 3, site 4 and site 5 were less than 0 . The FS of site 2, site 3 , site 4 and site 5 were greater than 23. Based on the classification of the PL and FS, the site 1 is almost certain that it will liquefy for Mw 6.69. The PG for the site 1 was varies from 0.0073 to 0.993. While the PG for site 2 , site 3 , site 4 and site 5 was nearly zero. The description of the risk of liquefaction induced ground failure for the site 1 ranges from low to extremely high. Finally, the description of the risk of liquefaction induced ground failure for the site 2 , site 3 , site 4 and site 5 ranges from extremely low to none. The LPI for site 1 (Fig.16) was shown that: (i) increases from surface to a depth of $9.3 \mathrm{~m}$, (ii) decreases at a depth of $11.5 \mathrm{~m}$ and (iii) finally goes 
to zero from $14.6 \mathrm{~m}$ to $30 \mathrm{~m}$. According to the LPI, only site 1 has very high liquefaction potential category. But, the site 2 , site 3 , site 4 and site 5 have no liquefaction potential for the given bedrock motion. The PG at the site 1 was found to be decreases at a depth of $11.5 \mathrm{~m}$ (Fig.16). As a result, the probability of liquefaction of ground failure will be high at a shallow depth. The PL (Fig.16) was shown that high at a shallow depth which ranges up to a depth of $10 \mathrm{~m}$ and decreases from $11.6 \mathrm{~m}$ to $30 \mathrm{~m}$.

Table: 3 LPI and Liquefaction potential category for site-1, 2, 3, 4 and 5 of Hawassa town, Southern Ethiopia.

\begin{tabular}{|l|l|l|l|}
\hline $\begin{array}{l}\text { Serial } \\
\text { Number }\end{array}$ & $\begin{array}{l}\text { ID } \\
\text { number }\end{array}$ & LPI & Liquefaction potential category \\
\hline 1 & Site-1 & 54.16 & Very high \\
\hline 2 & Site-2 & 0 & Very low \\
\hline 3 & Site-3 & 0 & Very low \\
\hline 4 & Site-4 & 0 & Very low \\
\hline 5 & Site-5 & 0 & Very low \\
\hline
\end{tabular}

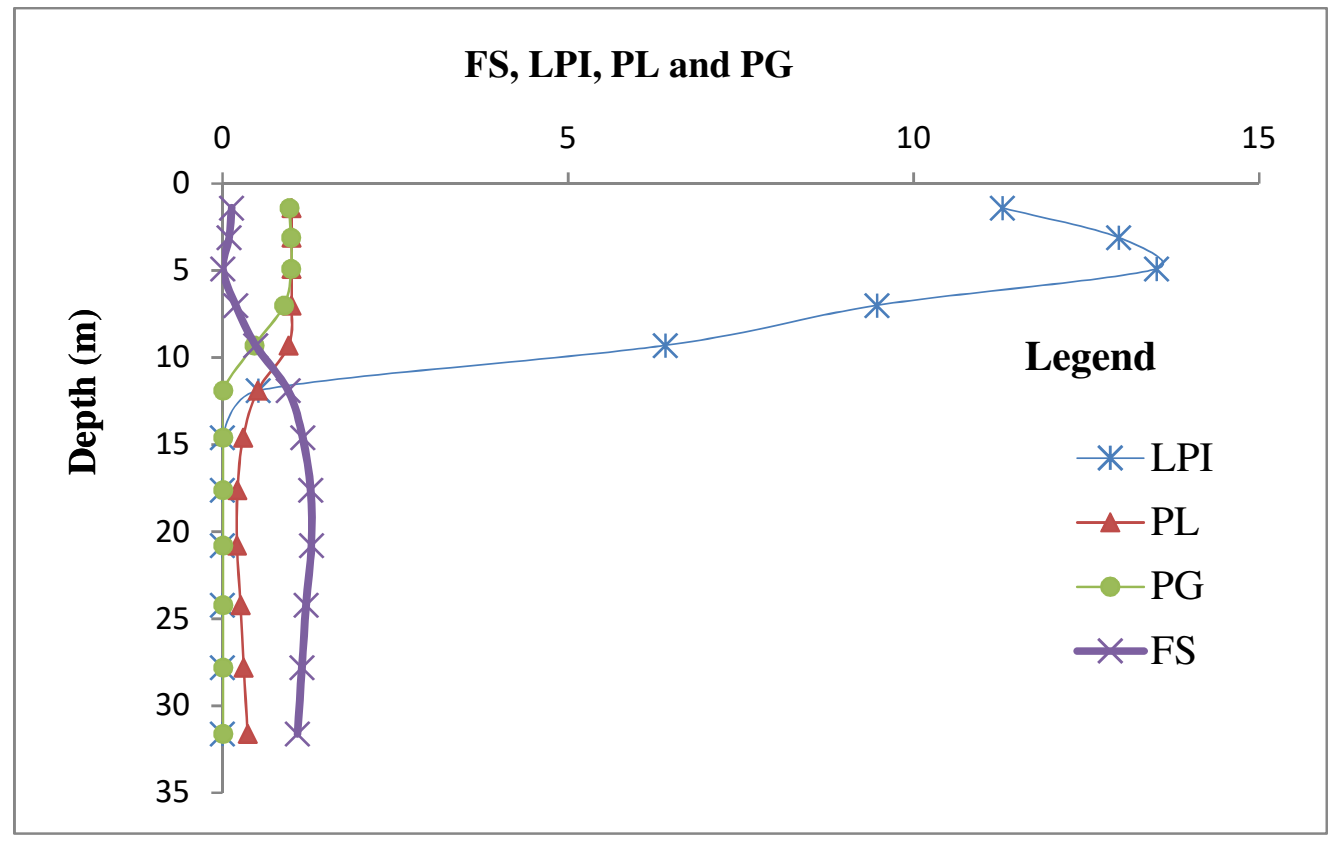

Fig.16 FS, LPI, PL and PG at the site 1 


\section{Conclusions}

This study evaluates local site effects and liquefaction hazard potential in Hawassa town in Southern Ethiopia. In order to investigate the local site effects and liquefaction potential analysis of the study area, different cases are considered based on the shear wave velocity and SPT-N values. In addition, the local site effects and liquefaction evaluation are investigated by deterministic approach. The equivalent linear response analysis, liquefaction susceptibility criteria, FS, LPI, PL and PG are the deterministic approach used for this study. The ground motion prediction parameters like PGA $(\mathrm{g})$, SA (g) and maximum strain (\%) are estimated for the study area to predict the occurrence of liquefaction for the earthquakes Mw6.69 with peak horizontal ground acceleration of $0.11 \mathrm{~g}$. The PGA $(\mathrm{g})$ is amplified from the bedrock motion to ground surface for the Northridge input motion at all the typical sites. All the typical sites shown that amplifying PGA (g) for the given ground motion. However, the maximum PGA (g) value is observed at the site 1 than site 2, site 3, site 4 and site 5 . The SA (g) is increased for the typical sites. But, the maximum SA (g) is revealed at site 1 than site 2 , site 3 , site 4 and site 5 . The results of maximum strain (\%) shown that deformation is occurred at the shallow depth for the typical sites and it reaches peak at the site 1. As a result, the typical sites need site-specific seismic design due to local site effects to minimize the settlement and deformation of civil structures.

The susceptibility criteria demonstrated that the study area soil is sandy soil. Therefore, study area soil is highly susceptible to liquefaction. In addition, at the site 1 , the FS $<1$ and LPI is equal to 54.16. Whereas FS>1 and LPI is equal to 0 for site 2, site 3, site 4 and site 5.Therefore, the probability of liquefaction and liquefaction category for site 1 is very high and very low for the site 2 , site 3 site 4 and site 5 . The PL for site 1 showed that almost certain that it will liquefy for Mw 6.69. But, the site 2, site 3, site 4 and site 5 are almost certain that it will not liquefy. In addition, the PG for the site 1 ranges from low to extremely high whereas PG ranges from extremely low to none. The results indicated that the site 1 has probability of liquefaction potential for all the approaches used for the liquefaction hazard evaluation. Therefore, site 1 needs more attention for the seismic design than site 2 , site 3 , site 4 and site 5 to seismic hazards. 


\section{Acknowledgements}

The author thanks both supervisors for the assistance of this paper. The author also thanks the Addis Ababa Science and Technology University (AASTU) and Wachamo University (WCU) for the providing me financial support. I acknowledge ARCON Design Build plc for the giving geotechnical data. The SDCSE is also thanked for the giving borehole data. Without Deepsoil software and Pacific Earthquake Engineering Research Center (PEER) database (http://peer.berkeley.edu), this article was not completed, as a result, they were acknowledged.

\section{Authors' contributions}

AA collected, processed, compiled, analyzed and simulation of site response data using DEEPSOILV.7 program and liquefaction analysis and write up for the completion of this manuscript. KWA technical editing, language improvement and the overall write up of the manuscript. MM technical editing, coordination and follow up of the manuscript. All authors read and approved the final manuscript.

\section{Availability of data and materials}

Some of the data analyzed during this study was included in this manuscript. In addition, the remaining datasets were used for this study are available with the corresponding author. Therefore, they would get based on the reasonable request.

\section{Funding}

Not available.

\section{Declaration of conflict of interest}

The authors declare that they have no competing interests. 


\section{Reference}

Agostini A, Bonini, M, Corti, G, Sani F, Mazzarini F (2011) Fault architecture in the Main Ethiopian Rift and comparison with experimental models: Implications for rift evolution and Nubia-Somalia kinematics. Earth and Planetary Science Letters 301: 479-492. https://doi.10.1016/j.epsl.2010.11.024

Akkaya İ, Özvan A (2019) Site characterization in the Van settlement (Eastern Turkey) using surface waves and HVSR microtremor methods. J Appl Geophys 160: 157-170

Akkaya İ, Özvan A, Akın M, Akın M, Övün U (2018) Comparison of SPT and Vs-based liquefaction analyses: a case study in Erciş (Van,Turkey). Acta Geophys 66: 21-38

Alemu, BE, Worku A, Wassie GM, Habtesellasie GT (2018) Ground Response Analysis of Representative Sites of Hawassa City. In Geotechnical Earthquake Engineering and Soil Dynamics V: Seismic Hazard Analysis, Earthquake Ground Motions, and Regional-Scale Assessment, Reston, VA: American Society of Civil Engineers 422-434

Andrus R.D, Stokoe II KH (1997) Liquefaction resistance based on shear wave velocity. In: Youd TL, Idriss IM (Eds.), NCEER Workshop on Evaluation of Liquefaction Resistance of Soils, Technical Report NCEER-97-0022, 89-128

Andrus R.D, Stokoe II KH (2000) Liquefaction resistance of soils from shear wave velocity. J Geotech. Geoenviron Eng ASCE 126 (11): 1015-1025

Andrus RD, Stokoe II K H, Roesset JM (1991) Liquefaction of gravelly soil at Pence Ranch during the 1983 Borah Peak, Idaho Earthquake. First International Conference on Soil Dynamics and Earthquake Engineering 251-262

Andrus RD, Stokoe II KH, Chung RM, Juang CH (2003) Guidelines for evaluating liquefaction resistance using shear wave velocity measurements and simplified procedures. National Institute of Standards and Technology 176

ARCON Design Build Plc (2018) Geotechnical investigation report of Hawassa town, Southern Ethiopia

Ayele A (2017) Probabilistic seismic hazard analysis (PSHA) for Ethiopia and the neighboring region. Journal of African Earth Sciences 134: 257-264

Ayele A, Woldearegay K, Meten M (2021) A review on the multi-criteria seismic hazard analysis of Ethiopia: with implications of infrastructural development. Geoenvironmental Disasters 8(1), 1-22.https://doi.org/10.1186/s4067-020-00175-7 
Bahari B, Hwang W, Kim TH, Song YS (2020) Estimation of liquefaction potential in Eco-Delta City (Busan) using different approaches with effect of fines content. International Journal of Geoengineering 11:14. https://doi.org/10.1186/s40703-02000121-4

Bird JF, Bommer JJ (2004) Earthquake losses due to ground failure. Engineering geology 75(2): 147-179

Bommer JJ, Stafford PJ, Alarcón JE (2009) Empirical equations for the prediction of the significant, bracketed, and uniform duration of earthquake ground motion. Bulletin of the Seismological Society of America 99(6): 3217-3233

Boore DM (2004 Estimating Vs (30) (or NEHRP Site Classes) from shallow velocity models (depths <30m) Bull. Seismo Am 94(2): 591-597

BSSC (Building Seismic Safety Council) (2015) 2015 Edition NEHRP recommended Seismic Provisions for New Buildings and Other Structures, FEMA P-1050-1 (Provisions and Commentary), Washington, D.C

Carlton B (2014) An improved description of the seismic response of sites with high plasticity soils, organic clays, and deep soft soil deposits. Dissertation, University of California

Carlton B, Abrahamson N (2014) Issues and approaches for implementing conditional mean spectra in practice. Bulletin of the Seismological Society of America 104(1): 503-51

Chen CJ Juang CH (2000) Calibration of SPT and CPT based liquefaction evaluation methods. In: Mayne PW, Hryciw R (eds) Innovations and applications in geotechnical site characterization, Geotechnical Special Publication 97: 49-64

Chorowicz J (2005) The East African rift system. Journal of African Earth Sciences 43:379410. https//: doi. 10.1016/j.jafrearsci.2005.07.019

Corti G, Philippon M, Sani F, Keir D, Kidane T (2013) Re-orientation of the extension direction and pure extensional faulting at oblique rift margins: Comparison between the Main Ethiopian Rift and laboratory experiments: Terra Nova 25: 396-404. https//:doi. 10.1111/ter.12049

Darendeli MB (2001) Development of a new family of normalized modulus reduction and material damping curves. Dissertation, University of Texas at Austin 
Dobry R, Ladd RS (1980) Discussion of soil liquefaction and cyclic mobility evaluation for level ground during earthquakes and liquefaction potential: Science Versus Practice. Journal of the Geotechnical Engineering Division 106(6): 720-724

Eker AM, Koçkar M K, Akgün H (2015) Evaluation of site effect within the tectonic basin in the northern side of Ankara. Engineering Geology 19:76-91

Eurocode-8 (2003) BS-EN 1998-1, Design of structures for earthquake resistance, part 1: General rules, seismic actions and rules for buildings, European Committee for Standardization, Brussels

Geotechnical Design Procedure (2015) Revision -3: Liquefaction potential of cohesionless soils, State of New York Department of Transportation Geotechnical Engineering Bureau

Hashash YMA, Musgrove MI, Harmon JA, Okan, I, Xing G, Groholski DR., Phillips CA, Park D (2020) DEEPSOIL 7.0, User Manual. Urbana, IL, Board of Trustees of University of Illinois at Urbana-Champaign

Idriss IM (1990) Response of soft soil sites during earthquakes. In Proceeding HB Seed Memorial Symp 2:273-289

Ishihara K (1985) Stability of Natural deposits during Earthquakes. Proceedings: 11th International Conference on Soil Mechanics and Foundation Engineering 1: 321-376.

Iwasaki T (1986) Soil liquefaction studies in Japan, State-of- Art. Soil Dyn Earthq Eng 5(1): 268. https//: doi.10.1016/0267-7261(86)90024-2

Iwasaki T, Tokida K, Tatsuoka F, Watanabe S, Yasuda S, Sato H (1982) Microzonation for soil liquefaction potential using simplified methods. Proceedings of the 3rd international conference on microzonation 3:1310-1330

Iwaski, Arakawa T, Tokida K (1986) Simplified procedures for assessing soil liquefaction during earthquakes. Proceeding of the Conference on Soil Dynamics and Earthquake Engineering 925-939

Juang C, Ching J, LuoZ, Ku C-S (2012) New models for probability of liquefaction using standard penetration tests based on an updated database of case histories. Engineering Geology 134:85-93. http//:doi. 10.1016/j.enggeo.2012.02.015

Juang CH, Yuan H, Lee DH, Lin PS (2003) A simplified CPT-based method for evaluating liquefaction potential of soils. J Geotech Geoenviron Eng 129 (1):66- 80 
Kavazanjian, JE, Matasovib JN, Hadj-Hamou T, Sabatini PJ (1997) A report on Geotechnical Engineering Circular \# 3 Design Guidance: Geotechnical Earthquake Engineering for Highways, Volume II - Design Principles, Washington, D.C. 20590

Kebede F, Van Eck T (1997) Probabilistic seismic hazard assessment for the Horn of Africa based on seismotectonic regionalization. Tectonophysics 270(3-4): 221-237

Keranen K, Klemperer SL (2008) Discontinuous and diachronous evolution of the Main Ethiopian Rift: Implications for development of continental rifts: Earth and Planetary Science Letters 265: 96-111. http//: doi. 10.1016/j.epsl.2007.09.038

Keranen K, Klemperer SL, Gloaguen R (2004) Three-dimensional seismic imaging of a protoridge axis in the Main Ethiopian rift: Geology 32: 949. http//doi. 10.1130/G20737.1

Kondner RL, Zelasko JS (1963) Hyperbolic stress-strain formulation of sands. Second pan American Conference on Soil Mechanics and Foundation Engineering 289-324.

Kramer S (1996) Geotechnical Earthquake Engineering. Prentice-Hall, Upper Saddle

Li DK, Juang CH, Andrus RD (2006) Liquefaction potential index: A critical assessment using probability concept. Journal of GeoEngineering 1(1):11-24

Liu AH, Stewart JP, Abrahamson NA, Moriwaki Y (2001) Equivalent number of uniform stress cycles for soil liquefaction analysis. Journal of Geotechnical and Geoenvironmental Engineering 127(12):1017-1026

Mammo T (2015) Site-specific ground motion simulation and seismic response analysis at the proposed bridge sites within the city of Addis Ababa. Ethiopia Eng Geo 79(3-4):127-150

Marcuson WF (1978) Definition of terms related to liquefaction. J Geotech Eng Div 104:11971200

Nath R.R, Jakka R. S (2012) Effect of bedrock depth on site classification. In $15^{\text {th }}$ world conference on earthquake engineering 15: 24-28

Özaydın K (2007) Liquefaction on Soils. $6^{\text {th }}$ Earthquake Engineering Congress in Istanbul, Turkey 231-255

Papathanassiou G, Seggis K, Pavlides S (2011) Evaluating earthquake induced liquefaction in the urban area of Larissa, Greece. Bull Eng Geol Environ 70(1):79-88

PEER (Pacific earthquake engineering center) (2010) Strong Ground motion database user manual, Beta Version 
Rahman MZ, Hossain MS, Kamal AM, Siddiqua S, Mustahid F, Farazi AH (2018) Seismic site characterization for Moulvibazar town, Bangladesh. Bulletin of Engineering Geology and the Environment 77(4): 1451-1471

Rahman MZ (2019) Probabilistic seismic Hazard analysis with nonlinear site response and liquefaction potential evaluation for deep sedimentary deposits, Dissertation, University of British Columbia (Okanagan)

Rahman Z, Siddiqua S (2017) Evaluation of liquefaction-resistance of soils using standard penetration test, cone penetration test, and shear-wave velocity data for Dhaka, Chittagong, and Sylhet cities in Bangladesh. Environ Earth Sci 76:207. http//:doi. 10.1007/s12665-017-6533-9

Robertson PK, Woeller DJ, Finn WDL (1992) Seismic cone penetration test for evaluating liquefaction potential under cyclic loading. Can Geotech J 29: 686-695

Sana H, Nath SK (2016) Liquefaction Potential Analysis of the Kashmir Valley Alluvium, NW Himalaya, Soil Dynamics and Earthquake Engineering http/:doi: 10.1016/j.soildyn.2016.03.009

Seed H B, Peacock W H (1971) Test procedures for measuring soil liquefaction characteristics. Journal of the Geotechnical Engineering Division 97(8): 1099-1119

Seed H.B (1968) The fourth Terzaghi lecture: Landslides during earthquakes due to liquefaction. Journal of the Soil Mechanics and Foundations division 94(5):1053-1122

Seed H.B, Idriss I.M (1971) Simplified procedure for evaluating soil liquefaction potential. Journal of Soil Mechanics and Foundation 97:1249 - 1273

Seed HB, Idriss IM (1970) Soil moduli and damping factors for dynamic response analyzes. Report No: EERC 70-10, EERC, university of California

Seed HB, Idriss IM (1982) Ground motions and soil liquefaction during earthquakes. Earthquake Engineering Research Institute Monograph, Oakland

Seed HB, Tokimatsu K, Harder LF, Chung RM (1984) The Influence of SPT procedures in soil liquefaction resistance evaluations report no. UCB/EERC-84/15. Earthquake Engineering Research Center, Berkeley, California

Seed HB, Wong RT, Idriss IM Tokimatsu K (1986) Moduli and damping factors for dynamic analyses of cohesionless soils. Journal of the soil mechanics and foundations division 112(11): 1016-1032 
Seed RB, Cetin KO, Moss RES, Kammerer AM, Wu J, Pestana JM, Riemer MF, Sancio RB, Bray JD, Kayen RE, Faris A (2003) Recent advances in soil liquefaction engineering: a unified and consistent framework, EERC-2003-06. Earthquake Engineering Research Institute, Berkeley, California

Seged H, Haile M (2010) Earthquake induced liquefaction analysis of Tendaho earth-fill dam. Zede Journal 27:1-11

Sherif MA, Ishibashi I, Tsuchiya C (1977) Saturation effects on initial soil liquefaction. Journal of the Geotechnical Engineering Division 103(8)

Sonmez (2003) Modification of the liquefaction potential index and liquefaction susceptibility mapping for a liquefaction-prone area (Inegol, Turkey). Environmental Geology 44(7):862-871

South Design and Construction Supervision Enterprise (SDCSE) (2019) Groundwater exploration Water Supply Project draft report of Hawassa town, Southern Ethiopia

Sykora D W (1987) Creation of a data base of seismic shear wave velocities for correlation analysis. Geotechnical Laboratory, Miscellaneous Paper GL-87-26, U.S. Army Engineer Waterways Experiment Station, Vicksburg, MS

Tang XW, Zhang XW, Uzuoka R (2015) Novel adaptive time stepping method and its application to soil seismic liquefaction analysis. Soil Dynamics and Earthquake Engineering 71:100-113

Tehran B, Mehrzad B, Haddad A, Jafarian Y (2016) Centrifuge and numerical models to investigate liquefaction-induced response of shallow foundations with different contact pressures. Int J Civ Eng 14(2):117-131

Tsuchida H (1970) Prediction and Countermeasure against the Liquefaction in sand deposits. Abstract of the Seminar in the Port and Harbor Research Institute (in Japanese)

Uyanık O (2002) Potential liquefaction analysis method based on shear wave velocity. Dissertation, Dokuz Eylul University of Turkey

Uyanık O, Ekinci B, Uyanık NA (2013) Liquefaction analysis from seismic velocities and determination of lagoon limits Kumluca/Antalya example. Journal of Applied Geophysics 95: 90-103 
Uyanik O, Taktak A G (2009) A New Method for Liquefaction Analysis from shear wave velocity and predominant resonance period. Journal of Natural and Applied Sciences $13(1)$

Walker AJ, Steward HE (1989) Cyclic undrained behavior of nonplastic and low plasticity silts. Technical Report NCEER-89-0035, National Center for Earthquake Engineering Research

Wilks M, Ayele A, Kendall JM, Wookey J (2017) The 24th January 2016 Hawassa earthquake: Implications for seismic hazard in the Main Ethiopian rift. Journal of African Earth Sciences 125: 118-125

Woldegabriel G (1990) Geology, Geochronology and Rift, Addis Ababa, Ethiopia

Yee E, Stewart JP, Tokimatsu K (2013) Elastic and large-strain nonlinear seismic site response from analysis of vertical array recordings. Journal of Geotechnical and Geoenvironmental Engineering 139(10): 1789-1801

Yoshida N (2015) Seismic ground response analysis. Dordrecht, Springer Netherlands

Yoshida N, Tokimatsu K, Yasuda S, Kokusho T, Okimura T (2001) Geotechnical aspects of damage in Adapazari city during 1999 Kocaeli, Turkey earthquake. Soils and foundations 41(4):25-45

Youd TL, Hoose SN (1977) Liquefaction susceptibility and geologic setting. In: Proceedings of 6th world conference on earthquake engineering 6: 37-42

Youd TL, Idriss IM, Andrus RD (2001) Liquefaction resistance of soils: summary report from the 1996 NCEER 14 and 1998 NCEER/NSF workshop on evaluation of liquefaction resistance of soils. J Geotech Geoenviron Eng 127:817-833

Youd TL, Perkins DM (1987) Mapping of liquefaction severity index. Journal of Geotechnical Engineering 113 (11): 1374-1392

Žáček V, Rapprich V, Aman Y, Berhanu B, Čížek D, Dereje K, Erban V, Ezra T, Firdawok L, Habtamu M., Hroch T, Kopačková V, Málek J, Malík J, Mišurec J, OrgoňA, Pécskay Z, Š́ma J, Tarekegu D, Verner K (2014) Explanation booklet to the Set of Geoscience maps of Ethiopia at a scale 1: 50,000: sub-sheet 0738-C4 Hawassa. 46 pgs., 3 annexes, 4 maps. Czech Geological Survey, Prague; AQUATES a.s., Prague; Geological Survey of Ethiopia, Addis Ababa 